\title{
NQO1, MPO, and the risk of lung cancer: A HuGE review
}

Chikako Kiyohara, $P h D^{1}$, Kouichi Yoshimasu, $M D, P h D^{2}$, Koichi Takayama, $M D, P h D^{3}$, and Yoichi Nakanishi, $\mathrm{MD}, \mathrm{PhD}^{3}$

\begin{abstract}
The aim of this study is to summarize the available molecular epidemiologic studies of lung cancer and metabolic genes, such as $\mathrm{NAD}(\mathrm{P}) \mathrm{H}$ quinone reductase 1 (NQO1) and myeloperoxidase (MPO). NQO1 plays a dual role in the detoxification and activation of procarcinogens whereas MPO has Phase I activity by converting lipophilic carcinogens into hydrophilic forms. Variant genotypes of both NQ01 Pro187 Ser and MPO G-463A polymorphisms may be related to low enzyme activity. The Pro/Ser and Ser/Ser genotypes combined of NQO1 was significantly associated with decreased risk of lung cancer in Japanese [random effects odds ratio (OR) $=0.70,95 \%$ confidence interval $(\mathrm{Cl})=0.56-0.88$ ] among whom the variant allele is common. The variant genotype of $M P O$ was associated with decreased risk of lung cancer among Caucasians (random effects $\mathrm{OR}=0.70,95 \% \mathrm{Cl}=$ 0.47-1.04). Gene-environment interactions in both polymorphisms may be hampered by inaccurate categorization of tobacco exposure. Evidence on gene-gene interactions is extremely limited. As lung cancer is a multifactorial disease, an improved understanding of such interactions may help identify individuals at risk for developing lung cancer. Such a study should include larger sample size and other polymorphisms in the metabolism of tobaccoderived carcinogens and address interactions with smoking status. The effects of polymorphisms are best represented by their haplotypes. In future studies on lung cancer, the development of haplotype-based approaches will facilitate the evaluation of haplotypic effects, either for selected polymorphisms physically close to each other or for multiple genes within the same drug-metabolism pathway. Genet Med 2005:7(7):463-478.
\end{abstract}

Key Words: lung cancer, $N A D(P) H$ quinone oxidoreductase 1 polymorphism, myeloperoxidase polymorphism, molecular epidemiology, meta-analysis

\section{GENES}

\section{NAD(P)H quinone reductase 1}

$\mathrm{NAD}(\mathrm{P}) \mathrm{H}$ quinone oxidoreductase 1 (NQO1, EC 1.6.99.2), formerly referred to as DT-diaphorase, is an important flavoprotein that catalyzes the two-electron reduction of carcinogenic quinoid compounds into their reduced form, such as hydroquinones. ${ }^{1}$ Benzo(a)pyrene (BP) is one of the most important carcinogens, and the formation of $\mathrm{BP}$ quinone-DNA adduct is prevented by NQO1. ${ }^{2}$ In contrast, carcinogenic heterocyclic amines present in smoke are metabolically activated by NQO1. ${ }^{3}$ Therefore, this enzyme is thought to be involved in both metabolic activation and detoxification of carcinogens. Higher levels of tissue (cyto-

From the ${ }^{I}$ Department of Preventive Medicine, Graduate School of Medical Sciences, Kyushu University, Fukuoka, Japan; ${ }^{2}$ Department of Hygiene, School of Medicine, Wakayama Medical University, Wakayama Japan; ${ }^{3}$ Research Institute for Diseases of the Chest, Graduate School of Medical Sciences, Kyushu University, Fukuoka, Japan.

Chikako Kiyohara, Department of Preventive Medicine, Division of Social Medicine, Graduate School of Medical Sciences, Kyushu University, Maidashi 3-1-1, Higashi-ku, Fukuoka 812-8582, Japan.

Received: May 11, 2005.

Accepted: May 24, 2005.

DOI: 10.1097/01.GIM.0000177530.55043.c1 plasm) expression of the NQO1 have been detected in the lung, kidney, liver, and skeletal muscle, with lower levels in the heart, brain, and placenta. ${ }^{4}$

\section{Myeloperoxidase}

Myeloperoxidase (MPO, EC 1.11.1.7) is a lysosomal hemoprotein located in the azurophilic granules of polymorphonuclear leukocytes and monocytes. MPO is the most abundant protein in neutrophils, constituting approximately $5 \%$ of their dry weight. ${ }^{5}$ MPO has Phase I metabolizing activity by converting lipophilic carcinogens into hydrophilic forms. ${ }^{6}$ Exposure to a variety of pulmonary insults, including cigarette smoke, stimulates recruitment of neutrophils into lung tissue ${ }^{7}$ with local release of MPO. ${ }^{8,9}$ MPO has been shown to activate an intermediate metabolite of $\mathrm{BP}$, the 7,8-diol BP, to the highly reactive and carcinogenic benzo(a)pyrene 7,8-diol-9,10 epoxide (BPDE) ${ }^{10}$ and to enhance the binding to BPDE to lung DNA in vitro. ${ }^{11}$ MPO also activates carcinogens in tobacco smoke including polycyclic aromatic hydrocarbons (PAHs), ${ }^{10-12}$ aromatic amines, ${ }^{13-15}$ and heterocyclic amines ${ }^{16}$ and catalyzed the endogenous formation of carcinogenic free radicals. ${ }^{17} \mathrm{MPO}$ may also function as an antimicrobial agent in neutrophils by catalyzing the production of genotoxic hypochlorous 
acid and other reactive oxygen species. ${ }^{18}$ Upon activation of the neutrophils, MPO is released into phagocytic vacuoles and the extracellular milieu. ${ }^{19,20}$

\section{VARIANTS}

\section{NQ01 variants}

The NQO1 gene, which is also known as DTD, QR1, DHQU, DIA4, or NMORI, consists of 6 exons and 5 introns and is located on chromosome 16q22.1. It covers $35.35 \mathrm{~kb}$, from 69536903 to 69501551 , on the reverse strand. A common polymorphic variant is a C-to-T point mutation at position 609 of exon 6 of the NQO1 cDNA that encodes for a proline to serine substitution at position 187 in the amino acid sequence of the protein. The three genotypes of this gene are the Pro/Pro (normal activity), the Pro/Ser (mild activity), and the Ser/Ser (2-4\% of normal activity). ${ }^{21-25}$ The genotype frequencies in different populations are shown in Table 1.26-65 The summary frequency of the Ser allele among Caucasians was 18.9\% (95\% $\mathrm{CI}=15.6-22.1 \%)$, and the summary frequency of the Ser/Ser and Pro/Ser genotypes combined was $31.8 \%$ (95\% CI $=$ $30.0-33.7 \%){ }^{26-42}$ The Ser allele (summary frequency $=$ $43.0 \%, 95 \%$ CI $=39.8-46.2 \%)$ was predominant among Asians; $68 \%$ (95\% CI $=64-72 \%)$ of the individuals had the Ser/Ser and Pro/Ser genotypes combined. ${ }^{51-63}$ The frequency of Ser allele in Asians was approximately 2.3-times more than in Caucasians. The only other mutation in the exon 2 is a Gto-A transition (G8015A) leading to a synonymous mutation. ${ }^{66}$ Other single nucleotide polymorphisms of this gene are in the $5^{\prime}$-flanking region and intron $1 .{ }^{66}$

\section{MPO variants}

The MPO gene is located on chromosome 17q23.1, consists of 11 introns and 12 exons. It covers $11.10 \mathrm{~kb}$, from 56832934 to 56821840 , on the reverse strand. A common G to A transition at position -463 in the promoter region of the $M P O$ gene, which leads to the loss of a SP1 transcription binding site in an Alu hormone-responsive element, ${ }^{67,68}$ has been shown to reduce $M P O$ mRNA expression. ${ }^{68,69}$ Because transcriptional activity is decreased in individuals with the variant $A$ allele, less enzyme would ultimately be available for conversion of the BP intermediate to the highly carcinogenic BPDE. As shown in Table 2, the summary frequency of the A allele has been found to be $23.4 \%$ (95\% CI $=21.8-25.0 \%)$ in Caucasians and $14.4 \%$ $(95 \%$ CI $=11.3-17.6 \%)$ in Asians. ${ }^{36,46,50,62,70-101}$ The A allele was more frequently (1.6 times) observed in Caucasians than in Asians. Three missense mutations associated with MPO deficiency have been described, namely Tyr 173Cys (exon 4), ${ }^{102}$ Met251Thr (exon 6, T4311C), ${ }^{103}$ and Arg569Trp (exon 10). ${ }^{104}$ Recently, another G-to-A transition at position -129 in the promoter region of the $M P O$ gene was described. ${ }^{105}$ There are no reports of these polymorphisms in relation to lung cancer risk.

\section{Disease}

Although the incidence has peaked in the United States and most of Europe, lung cancer is showing increasing incidence and mortality in many countries around the world. An estimated 1,239,000 (902,000 males and 337,000 females) new cases of lung cancer were diagnosed worldwide in 2000, accounting for $12.3 \%$ of all new cases of cancer, and 1,103,000 (810,000 males and 293,000 females) died from the disease, accounting for $17.8 \%$ of all deaths from cancer. ${ }^{106}$ This disease ranks as the foremost cancer killer in men and the second largest in women. The case fatality (ratio of mortality to incidence), which is an indicator of prognosis, is 0.89 for lung cancer (the third-worst). Other cancers with bad prognosis are pancreas (0.99, the worst) and liver (0.97, the second-worst) cancers. ${ }^{107}$

Worldwide, the incidence rate in men exceeds that in women by a factor of 2.7. Lung cancer mortality among men is now abating in several countries, whereas the mortality in women continues to climb in most countries, as predicted by later onset tobacco abuse. ${ }^{108}$ Principal histological types of lung cancer are squamous cell carcinoma, large cell carcinoma, small cell carcinoma, and adenocarcinoma, and the former three are strongly associated with smoking. In recent decades, the frequency of adenocarcinoma has risen and that of squamous cell carcinoma has declined in a number of developed couries. ${ }^{109-115}$ The increase in incidence of adenocarcinoma could be partly explained by an increase in filtered cigarette smoking. Filter cigarettes with low-tar and low-nicotine have replaced nonfilter cigarettes. One key characteristic of such changes over time has been the increased nitrate content of the tobacco blend from about $0.5 \%$ to $1.3 \% .{ }^{116}$ Tobacco-specific $\mathrm{N}$-nitrosamines (TSNAs) are formed by $\mathrm{N}$-nitrosation of nicotine and other minor alkaloids during tobacco processing and smoking. ${ }^{117}$ Because nitrate is the major precursor for nitrogen oxides, increased nitrate content leads to higher yields of 4-(methylnitrosamino)-1-(3-pyridyl)-1-butanone (NNK) in the smoke. ${ }^{118}$ To satisfy the craving for nicotine, a smoker of low-yield nicotine filtered cigarettes may tend to compensate by increasing the number and depth of puffs. Therefore, the peripheral lung, where adenocarcinoma generally arises, is exposed to a higher amount of smaller particles such as NNK. NNK is a systemic carcinogen that induced lung carcinoma in laboratory animals, whereas intratracheal instillation of PAHs preferentially induced squamous cell carcinoma. ${ }^{119}$ It is biologically plausible that TSNAs such as NNK cause adenocarcinoma in humans.

\section{Smoking}

Most of the lung cancer debate has been focused on tobacco smoking. Given the many risk factors that have been identified for lung cancer, a practical question is the relative contribution of these factors to the summary burden of lung cancer. The population attributable fraction (PAF) takes into account the magnitude of relative risk that is associated with an exposure along with the likelihood of exposure in the general population. The WHO Global Burden of Disease 2000 study reported that the PAF of lung cancer mortality due to smoking was $79 \%$ in men and $48 \%$ in women. ${ }^{120}$ The risk among smokers relative to the risk among never-smokers is 8 to 15 times in men and 2 


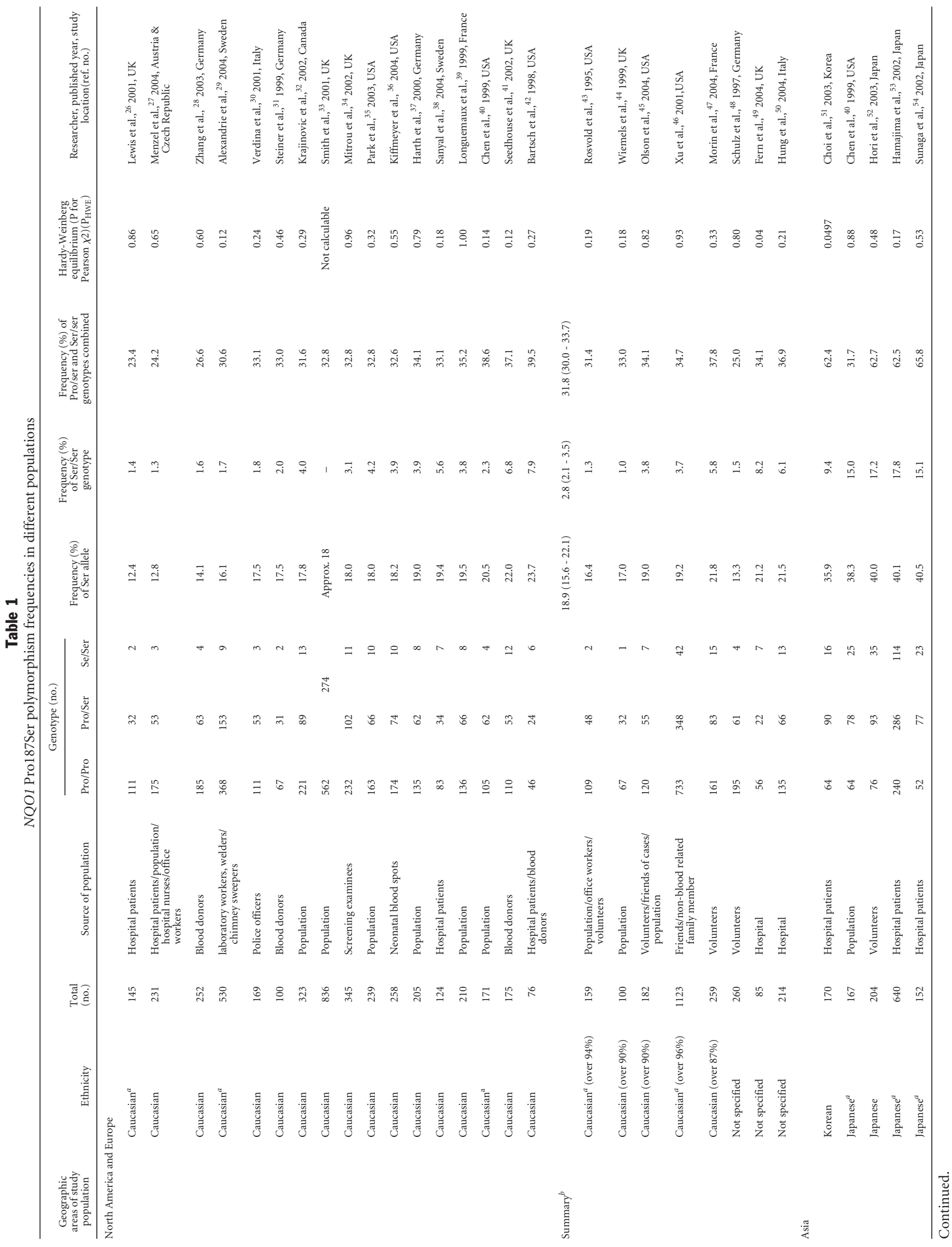




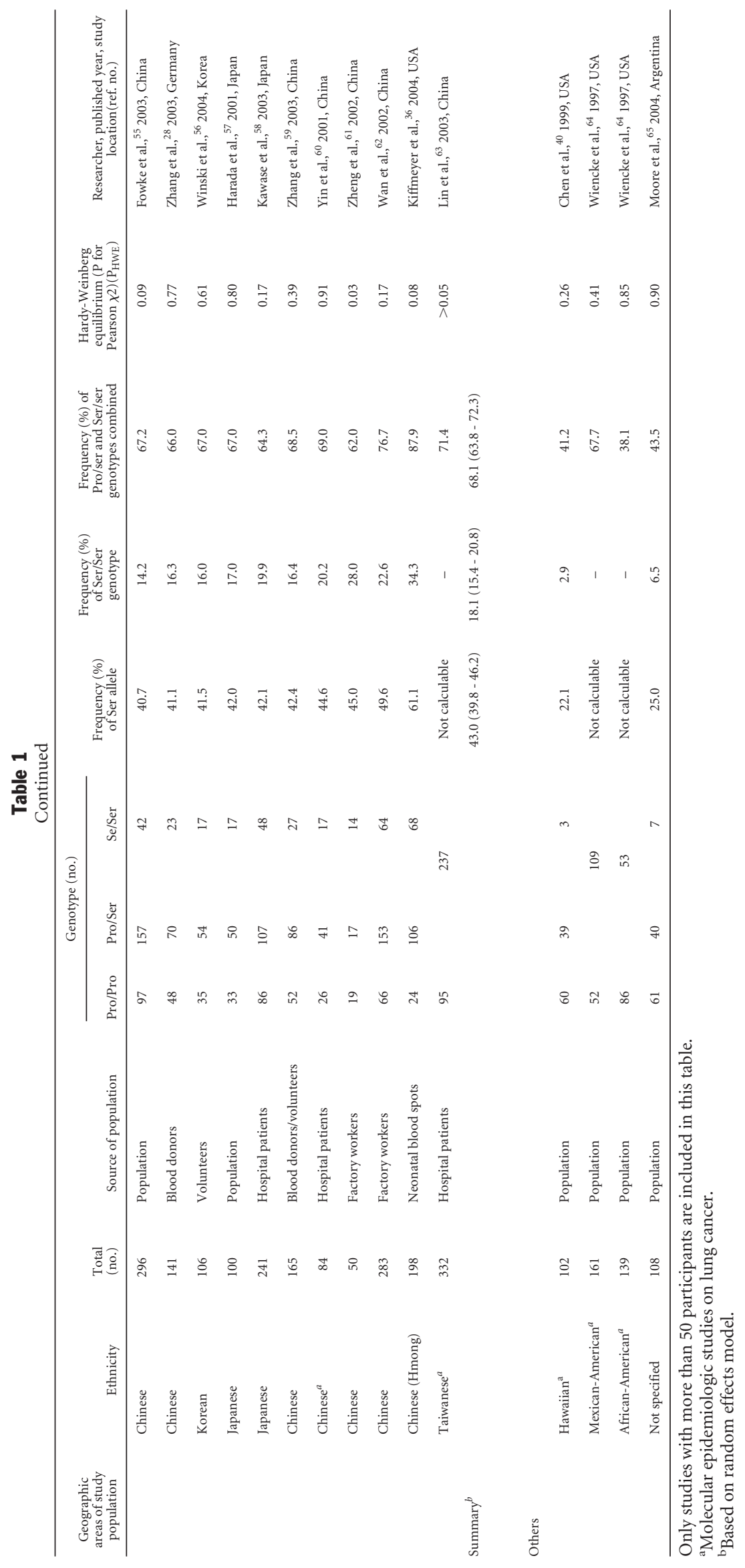


Table 2

MPO G-463A polymorphism frequencies in different populations

\begin{tabular}{|c|c|c|c|c|c|c|c|c|c|c|}
\hline \multirow{2}{*}{$\begin{array}{l}\text { Geographic } \\
\text { areas of } \\
\text { study } \\
\text { population }\end{array}$} & \multirow[b]{2}{*}{ Ethnicity } & \multirow{2}{*}{$\begin{array}{l}\text { Total } \\
\text { (no.) }\end{array}$} & \multirow[b]{2}{*}{ Source of population } & \multicolumn{3}{|c|}{ Genotype (no.) } & \multirow{2}{*}{$\begin{array}{l}\text { Frequency }(\%) \\
\text { of A allele }\end{array}$} & \multirow{2}{*}{$\begin{array}{l}\text { Frequency (\%) } \\
\text { of A/A genotype }\end{array}$} & \multirow{2}{*}{$\begin{array}{l}\text { Hardy-Weinberg } \\
\text { equilibrium }(\mathrm{P} \text { for } \\
\text { Pearson } \chi 2)\left(\mathrm{P}_{\mathrm{HWE}}\right)\end{array}$} & \multirow{2}{*}{$\begin{array}{l}\text { Researcher, published year, study } \\
\text { location (ref. no.) }\end{array}$} \\
\hline & & & & $\mathrm{G} / \mathrm{G}$ & G/A & $\mathrm{A} / \mathrm{A}$ & & & & \\
\hline \multicolumn{11}{|c|}{ North America and Europe } \\
\hline & Caucasian & 174 & Hospital patients & 117 & 54 & 3 & 17.2 & 1.7 & 0.25 & Reynolds et al. ${ }^{70} 2000$, Finland \\
\hline & Caucasian & 241 & Hospital patients & 159 & 75 & 7 & 18.5 & 2.9 & 0.60 & Kantarci et al., ${ }^{71} 2000$, USA \\
\hline & Caucasian & 369 & Neonatal blood spots & 235 & 126 & 8 & 19.2 & 2.2 & 0.06 & Kiffmeyer et al., ${ }^{36} 2004$, USA \\
\hline & Caucasian $^{a}$ & 311 & Population & 206 & 84 & 21 & 20.3 & 6.8 & 0.04 & Misra et al., ${ }^{72} 2001$, USA \\
\hline & Caucasian $^{a}$ & 340 & Hospital patients & 218 & 105 & 17 & 20.4 & 5.0 & 0.35 & Dally et al., ${ }^{73} 2002$, Germany \\
\hline & Caucasian $^{a}$ & 196 & Hospital patients & 117 & 75 & 4 & 21.2 & 2.0 & 0.04 & Cascorbi et al., ${ }^{74} 2000$, Germany \\
\hline & Caucasian & 270 & Volunteers & 165 & 94 & 11 & 21.5 & 4.1 & 0.60 & Cascorbi et al., ${ }^{74} 2000$, Germany \\
\hline & Caucasian & 145 & Population & 86 & 55 & 4 & 21.7 & 2.8 & 0.17 & Nelissen et al., ${ }^{75} 2000$, Sweden \\
\hline & Caucasian & 449 & Hospital patients & 274 & 152 & 23 & 22.0 & 5.1 & 0.75 & Hoy et al., ${ }^{76} 2003$, France \\
\hline & Caucasian & 243 & Population & 143 & 88 & 12 & 23.0 & 4.9 & 0.74 & Rutgers et al. ${ }^{77} 2003$, The Netherlands \\
\hline & Caucasian & 191 & Population & 113 & 68 & 10 & 23.0 & 5.2 & 0.96 & Rothkrantz-Kos et al., ${ }^{78} 2003$, The Netherlands \\
\hline & Caucasian $^{a}$ & 459 & $\begin{array}{l}\text { Samples from driver's license }(<65 \\
\text { years }) / \text { Medicare beneficiaries }(\geq 65 \text { years })\end{array}$ & 280 & 143 & 36 & 23.4 & 7.8 & 0.005 & London et al., ${ }^{79} 1997$, USA \\
\hline & Caucasian $^{a}$ & 245 & Hospital patients & 140 & 93 & 12 & 23.9 & 4.9 & 0.49 & Chevrier et al. ${ }^{80} 2003$, France \\
\hline & Caucasian & 180 & Population & 102 & 65 & 13 & 25.3 & 7.2 & 0.55 & Pakakasama et al., ${ }^{81} 2003$, USA \\
\hline & Caucasian $^{a}$ & 171 & Population & 98 & 58 & 15 & 25.7 & 8.8 & 0.14 & LeMarchand et al., ${ }^{82} 2000$, USA \\
\hline & Caucasian $^{a}$ & 172 & Hospital patients & 96 & 63 & 13 & 25.9 & 7.6 & 0.55 & Feyler et al., ${ }^{83} 2002$, France \\
\hline & Caucasian & 217 & Hospital patients & 120 & 78 & 19 & 26.7 & 8.8 & 0.23 & Nikpoor et al., ${ }^{84} 2001$, Canada \\
\hline & Caucasian $^{a}$ & 119 & Population & 59 & 56 & 4 & 26.9 & 3.4 & 0.03 & Cajar-Salazar et al., ${ }^{85} 2003$, USA \\
\hline & Caucasian & 196 & Population & 100 & 84 & 12 & 27.6 & 6.1 & 0.30 & Borgmann et al.. ${ }^{86} 2003$, Germany \\
\hline & Caucasian & 166 & Population & 83 & 62 & 21 & 31.3 & 12.7 & 0.09 & Crawford et al., ${ }^{87} 2001$, USA \\
\hline & Caucasian & 95 & Hospital patients & 47 & 35 & 13 & 32.1 & 13.7 & 0.13 & Van Schooten et al., ${ }^{88} 2004$, The Netherlands \\
\hline & Caucasian & 158 & Population & 67 & 74 & 17 & 34.2 & 10.8 & 0.61 & Zappia et al., ${ }^{89} 2004$, Canada \\
\hline \multirow[t]{10}{*}{ Summary $^{b}$} & & & & & & & $23.4(21.8-25.0)$ & $5.4(4.3-6.6)$ & & \\
\hline & Caucasian $^{a}$ (over 96\%) & 1128 & Spouses and friends of patients & 697 & 390 & 41 & 20.9 & 3.6 & 0.13 & Xu et al., ${ }^{90} 2002$, USA \\
\hline & Caucasian $^{a}(95 \%)$ & 307 & Hospital patients & 181 & 111 & 15 & 23.0 & 4.9 & 0.70 & Kantarci et al., ${ }^{91} 2002$, USA \\
\hline & $\operatorname{Caucasian}^{a}(83 \%)$ & 378 & Office workers & 202 & 157 & 19 & 25.8 & 5.0 & 0.10 & Schabath et al., ${ }^{92} 2002$, USA \\
\hline & Caucasian (over 90\%) & 179 & Volunteers/friends of cases/population & 77 & 80 & 22 & 34.6 & 12.3 & 0.86 & Olson et al., ${ }^{46} 2004$, USA \\
\hline & Not specified & 1083 & Population & 714 & 340 & 29 & 18.4 & 2.7 & 0.13 & Meisel et al., ${ }^{93} 2002$, Germany \\
\hline & Not specified & 246 & Hospital patients & 157 & 84 & 5 & 19.1 & 2.0 & 0.10 & $\begin{array}{l}\text { Leininger-Muller et al., } .^{94} 2003 \text {, France, Spain, } \\
\text { Northern Ireland \& Croatia }\end{array}$ \\
\hline & Not specified & 115 & Blood donors/hospital employees & 74 & 37 & 4 & 19.6 & 3.5 & 0.81 & Buraczynska et al., ${ }^{95} 2003$, Poland \\
\hline & Not specified & 99 & Volunteers & 70 & 18 & 11 & 20.2 & 11.1 & 0.00000 & Zakrzewska-Pniewska et al., ${ }^{96} 2004$, Poland \\
\hline & Not specified & 214 & Hospital patients & 129 & 63 & 22 & 25.0 & 10.3 & 0.002 & Hung et al., ${ }^{50} 2004$, Italy \\
\hline \multicolumn{11}{|l|}{ Asia } \\
\hline & Chinese & 290 & Factory workers & 245 & 55 & 0 & 9.5 & Not calculable & 0.08 & Wan et al., ${ }^{62} 2002$, China \\
\hline & Japanese & 437 & Health check examinees & 354 & 77 & 6 & 10.2 & 1.4 & 0.44 & Katsuda et al., ${ }^{97} 2003$, Japan \\
\hline & Japanese & 241 & Hospital patients & 192 & 47 & 2 & 10.6 & 0.8 & 0.63 & Hamajima et al., ${ }^{98} 2001$, Japan \\
\hline & Chinesea & 320 & Population & 227 & 87 & 6 & 12.1 & 1.9 & 0.48 & Lu et al., ${ }^{99} 2002$, China \\
\hline & Chinese (Hmong) & 199 & Neonatal blood spots & 141 & 50 & 8 & 16.6 & 4.0 & 0.20 & Kiffmeyer et al., ${ }^{36} 2004$, USA \\
\hline & Japanesea & 163 & Population & 115 & 41 & 7 & 16.9 & 4.3 & 0.19 & LeMarchand et al., ${ }^{82} 2000$, USA \\
\hline Summary $^{b}$ & & & & & & & $14.4(11.3-17.6)$ & $1.9(0.8-2.9)$ & & \\
\hline & Not specified & 67 & Population & 153 & 12 & 2 & 11.9 & 3.0 & 0.22 & Choi et al., ${ }^{100} 2001$, India \\
\hline & Not specified & 104 & Population & 74 & 27 & 3 & 15.9 & 2.9 & 0.78 & Ahsan et al., ${ }^{101} 2003$, Bangladesh \\
\hline \multicolumn{11}{|l|}{ Others } \\
\hline & Hispanic & 75 & Population & 42 & 29 & 4 & 24.7 & 5.3 & 0.73 & Crawford et al., ${ }^{87} 2001$, USA \\
\hline & African-American $^{a}$ & 244 & $\begin{array}{l}\text { Samples from driver's license }(<65 \\
\text { years)/Medicare beneficiaries }(\geq 65 \\
\text { years) }\end{array}$ & 121 & 100 & 23 & 29.9 & 9.4 & 0.72 & London et al., ${ }^{77} 1997$, USA \\
\hline & Hawaiiana & 103 & Population & 81 & 17 & 5 & 26.2 & 4.9 & 0.005 & LeMarchand et al., ${ }^{82} 2000$, USA \\
\hline
\end{tabular}

Only studies with more than 50 participants are included in this table.

${ }^{\mathrm{a}}$ Molecular epidemiologic studies on lung cancer.

${ }^{\mathrm{b}}$ Based on random effects model. 
to 10 times in women. ${ }^{121}$ Smoking cessation significantly reduces lung cancer risk, and after many years the risk of exsmokers approaches that of never-smokers. It took more than 20 years for the risk in ex-smokers to approach the level in never-smokers. ${ }^{122}$ A recent meta-analysis showed that environmental tobacco smoke exposure from husbands conferred a 1.20 times increase in lung cancer risk among nonsmoking women. ${ }^{123}$

\section{Other risk factors}

The PAF for lung cancer deaths due to environmental tobacco exposure accounts for $0.7 \%, 0.2 \%$ in men and $2.5 \%$ in women. ${ }^{124}$ Doll and Peto estimated that approximately $20 \%$ of lung cancer deaths in the United States were potentially avoidable by the modification of diet. ${ }^{125}$ Willett also estimated that $20 \%$ (range, $10-30 \%$ ) was avoidable by dietary factors. ${ }^{126}$ The PAF for lung cancer deaths due to outdoor air pollution accounts for $1 \%$ to $3.6 \% .{ }^{127}$ Radon may be responsible for only $1 \%$ of lung cancers. ${ }^{128}$ In the USA, occupational exposure to carcinogens accounts for approximately $9 \%$ to $15 \%$ of lung cancer cases. ${ }^{129}$

\section{Genetic epidemiology}

Cigarette smoke contains several thousand chemicals. Most of these compounds are procarcinogens that must be activated by Phase I enzymes, such as cytochrome P450s (CYPs). All reactive carcinogens can bind to DNA and form DNA adducts that are capable of inducing mutations and initiating carcinogenesis. CYP1-CYP4 are primarily involved in the drug metabolism. ${ }^{130}$ Other Phase I enzymes are MPO, NQO1, microsomal epoxide hydrolase 1 (EPHX1), and alcohol dehydrogenase. A significant increased risk (2.4 to 3 times) of lung cancer for the CYP1A1 T3801C or A2455G (Ile462Val) polymorphisms was observed among Japanese ${ }^{131}$ and Caucasians. ${ }^{132}$ Although a molecular epidemiological association is possible between the prevalence of the high activity genotype of CYP2D6 and lung cancer, such an association, if it exists, could be weak. ${ }^{131}$ As for CYP2E1, no clear evidence has been found that the reported polymorphisms are related to lung cancer risk. ${ }^{131}$ Studies on other CYP2 subfamily have indicated a relation between lung cancer and the occurrence of a rare allele, although future research is needed to establish a significant association. ${ }^{131}$

After the Phase I reaction, Phase II enzymes like glutathione S-transferases (GSTs) are responsible for detoxifying the activated forms of PAH epoxides. The GSTs also form a superfamily. ${ }^{133,134}$ The major isoforms, which involve the metabolic activation of carcinogens derived from tobacco smoke or the detoxification of the respective activated carcinogens, are GSTM1, GSTM3, GSTT1, and GSTP1. Other Phase II enzymes are EPHX1, NQO1, N-acetyltransferases (NATs), UDPglucuronosyltransferase, aldehyde dehydrogenase, sulfotransferase, and superoxide dismutase. The GSTM1 null genotype and the concurrent lack of GSTM1 and GSTT1 may be modestly associated (approximately 2 times) with susceptibility to lung cancer. ${ }^{135}$ It may be of great importance to study both
NAT1 and NAT2 together as putative contributing factors for lung cancer susceptibility. ${ }^{136}$ Among metabolic polymorphisms, MPO, NQO1, and EPHX1 have been less reviewed than CYPs, GSTs, and NATs. The rest of the candidate genes remain little investigated.

The capacity to repair DNA damage induced by chemical carcinogens appears to be another host factor that may influence lung cancer risk. Potentially important DNA repair genes are 8-oxoguanine-DNA glycosylase $1, \mathrm{x}$-ray cross-complementing Group 1 (XRCC1), xeroderma pigmentosum C $(X P C)$, excision repair cross-complementing Group 1 (ERCC1), ERCC2 (XPD), ERCC3 (XPB), ERCC4 (XPF), ERCC5 $(X P G)$, xeroderma pigmentosum $\mathrm{C}(X P C)$, and $X R C C 3$. Although each DNA repair gene may not be a major determinant of lung cancer susceptibility, ERCC2 seems to be the most promising among DNA repair genes. ${ }^{137}$ Furthermore, cell-cycle control genes (p53, cyclins, etc.), genes that influence smoking behavior [dopamine receptor (DR) D2, DRD4, $D R D 5$, neuronal nicotine acetylcholine receptor, dopamine transporter and serotonin transporter] and genes involved in development of the immune system (interleukins and tumor necrosis factor) may have the potential to substantially affect lung cancer risk.

\section{META-ANALYSIS METHODS}

\section{Identification and eligibility of relevant studies}

We conducted a MEDLINE search using "NAD(P)H quinone reductase 1," "myeloperoxidase," "lung cancer," and "polymorphism" for articles published before August 2004. Additional articles were identified through the references cited in the first series of articles selected. Articles included in metaanalysis were English and non-English, human, published in the primary literature and had no obvious overlap of subjects with other studies. Case-control studies were eligible, if they had determined the distribution of the relevant genotypes in lung cancer cases and in concurrent controls using a molecular method for genotyping. We excluded studies with the same data or overlapping data by the same authors.

\section{Data extraction and assessment of study quality}

Two investigators (C.K. and K.Y.) independently extracted data and reached consensus on all items except for the HardyWeinberg equilibrium. The following items were sought from each report: authors, year of publication, place of study, ethnic group of the study population, characteristics of lung cancer cases (age distribution, sex ratio, histological type, smoking and occupational exposure), characteristics of controls (age distribution, sex ratio, source of population, smoking and occupational exposure), number of genotyped cases and controls, frequency of the genotypes, ORs, adjusted factors for OR, and the method for quality control of genotyping. For studies including subjects of different ethnic groups, data were extracted separately for each ethnic group, whenever possible.

Methods for defining study quality in genetic studies are more clearly defined than those for observational studies. We 
assessed the Hardy-Weinberg equilibrium via a goodness-offit $\chi^{2}$ test (Pearson) to compare the observed and expected genotype frequencies among controls. We also assessed the homogeneity of the study population (Caucasian only or mostly Caucasian).

\section{Meta-analysis}

Data were combined using both fixed effects (Mantel-Haenszel) and random effects (DerSimonian and Laird method) models. ${ }^{139}$ Fixed effects and random effects analyses address fundamentally different research questions. The former asks what the best estimate of the true effect size is in the population studied, whereas the latter asks what the range and distribution of effect sizes in the sample of populations studied. Therefore, the calculation of the mean of the distribution of population effect sizes (random effects model) provides different information from the calculation of the mean of the distribution of sample effect sizes (fixed effects model). Random effects incorporate an estimate of the between-study variance and tend to provide wider confidence intervals, when the results of the constituent studies differ among themselves. The random effects model, compared to the fixed effects model, reduces the weight for each individual study proportion to the difference in effect size of an individual study from the pooled estimate of the effect for all other studies. Random effects model are more appropriate when heterogeneity is present. ${ }^{138}$ Thus, estimates values were basically based on random effects model. Heterogeneity, evaluated by the Cochrane $\mathrm{Q}$ test ${ }^{139,140}$ among the studies, was considered significant for $P<0.10$. Both Begg's ${ }^{141}$ and Egger's ${ }^{142}$ tests were used to test for publication bias, which was considered significant for $P<0.10$. Both the tests could also assess whether larger studies give different results from small studies. In a sensitivity analysis (subgroup analysis), we combined only studies with allelic frequencies being in Hardy-Weinberg equilibrium (Pearson $\chi^{2}$ test, $P \geq 0.05$ ) because departure from Hardy-Weinberg equilibrium can imply the presence of genotyping error, possible ethnic admixture in the population or selection bias (short of representativeness of the general population). As the ethnic differences were observed in Tables 1 and 2, subgroup analyses by ethnic were also performed. Subgroup analyses by histologic type were performed if available. All the calculations were performed with computer program STATA Version 8.2 (Stata Corporation, College Station, TX).

\section{ASSOCIATIONS}

\section{NQ01 Pro187Ser polymorphism and lung cancer risk}

As the variant allele is related to low enzyme activity, subjects with at least one variant allele may be associated with decreased risk of lung cancer if NQO1 enzyme acts as a mechanism for metabolic activation of several carcinogens present in tobacco smoke. The Pro/Ser and Ser/Ser genotypes combined was significantly associated with decreased risk of lung cancer in Mexican-Americans. ${ }^{64}$ All three Japanese ${ }^{40,53,54}$ studies have also shown that the combined genotype was associated with decreased risk of lung cancer. In Chinese, ${ }^{60}$ Hawaiians, ${ }^{40}$ Caucasians, ${ }^{40}$ and African-Americans, ${ }^{64}$ the combined genotype was weakly associated with decreased risk of lung cancer. No evidence for an influence of genetic polymorphism in NQO1 on lung cancer risk was found in two Caucasian populations ${ }^{29,46}$ and one Taiwanese population. ${ }^{63}$ In contrast, the combined genotype ${ }^{26,43}$ was nonsignificantly associated with increased risk of lung cancer in Caucasians.

The 10 case-control studies in 13 different ethnic populations of lung cancer and the combined genotype included 2746 lung cancer cases and 3902 controls. As a clear gene-dose effect was suggested by the genotype-phenotype association studies, ${ }^{21-25}$ a genetic model (codominant or decreasing model), in which lung cancer risks of the genotypes Pro/Pro, Pro/Ser, and Ser/Ser decrease in that order, was applied. As the Ser/Ser genotype has not been separated due to a low prevalence of the rare Ser allele in several studies, we combined the Pro/Ser genotype with Ser/Ser genotype. In our meta-analysis, summary frequencies of the combined genotype among Caucasians and Japanese based on random effects model were $30.8 \%(95 \% \mathrm{CI}=23.6-38.0 \%)$ and $62.9 \%(95 \% \mathrm{CI}=59.8-$ $66.0 \%$ ), respectively (Table 3). The summary ORs for the combined genotype in Caucasians and Japanese were 1.12 (95\% CI $=0.96-1.47)$ and $0.70(95 \% \mathrm{CI}=0.56-0.88)$, respectively. Statistically significant heterogeneity $(P=0.032)$ was seen in case of all studies combined. This result was not reproduced in any sensitivity analysis. Possible sources of heterogeneity are ethnicity (the prevalence of the "at risk" allele, ethnic differences in roles of the polymorphism), study design, and so on. The Begg's test was statistically significant $(P=0.09)$ for publication bias but not the Egger's test $(P=0.11)$ in a sensitivity analysis among mostly Caucasian and Caucasian only populations, because the largest study of $\mathrm{Xu}$ et al. showed null association. ${ }^{46}$ The presence of heterogeneity and/or publication bias may compromise the interpretation of meta-analyses and result in an erroneous and potentially misleading conclusion. ${ }^{143,144}$ The presence of publication bias indicates that nonsignificant or negative findings remain unpublished. Although publication bias is always a possible limitation of combining data from various sources as in a meta-analysis, Sutton et al. concluded that publication or related biases did not affect the conclusions in most meta-analyses. ${ }^{145}$ The results of our meta-analysis indicate that the Ser allele, which is linked to low enzyme activity, was significantly associated with decreased risk of lung cancer in Asians among whom the variant allele is common. But such an association was not observed in Caucasians. The impact of NQO1 was different among different populations. Reasons for this apparent difference in risk with different ethnic populations are as yet unknown but, if real, may be related to other genetic or environmental factors.

Histologic data were available for six studies and four studies have indicated a significant association between NQO1 polymorphism and risk of certain histologic types of lung cancer. Small cell carcinomas were more likely to occur with a significant difference among those who had the Pro/Ser and Ser/Ser genotypes combined, compared to those who had two copies 


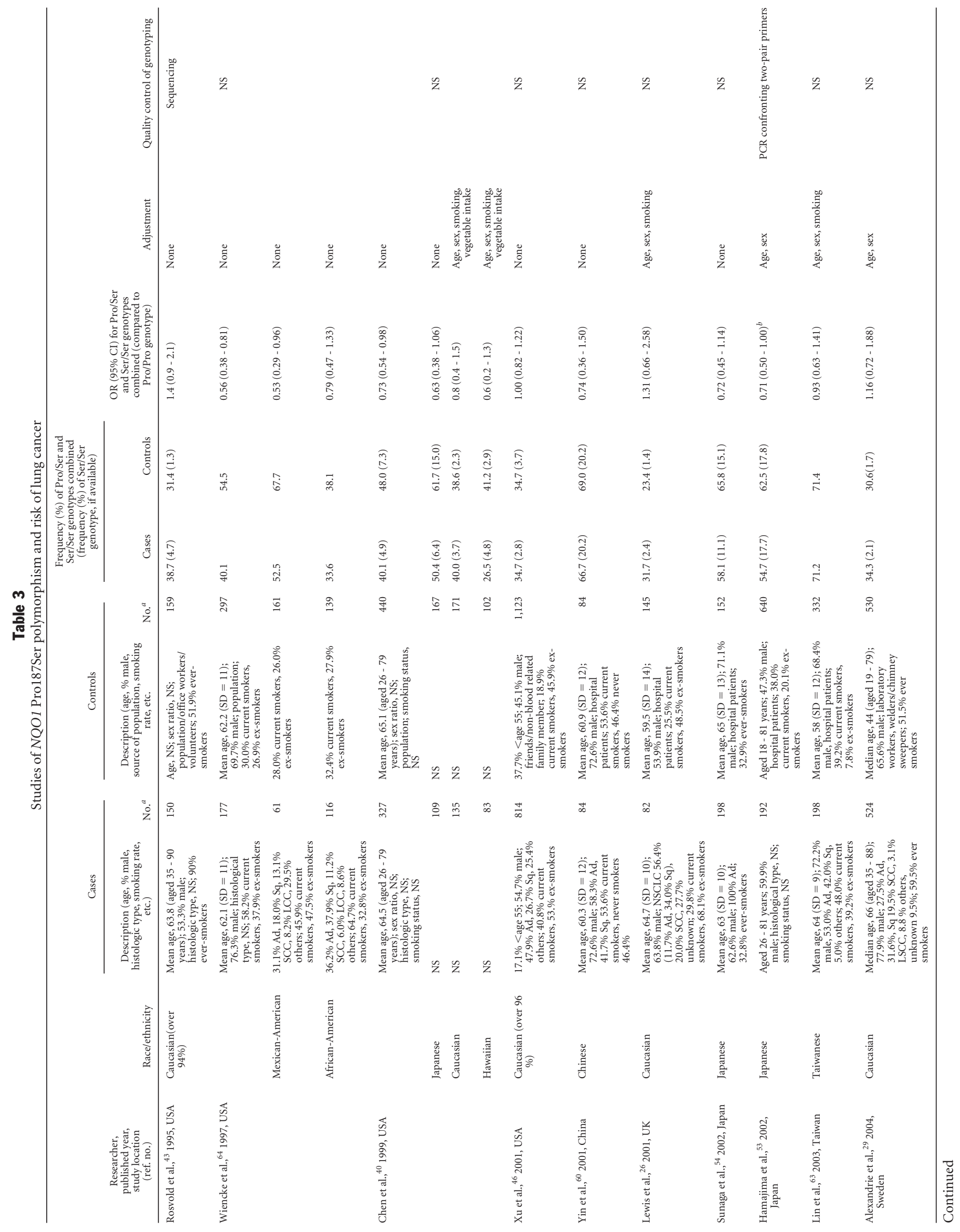




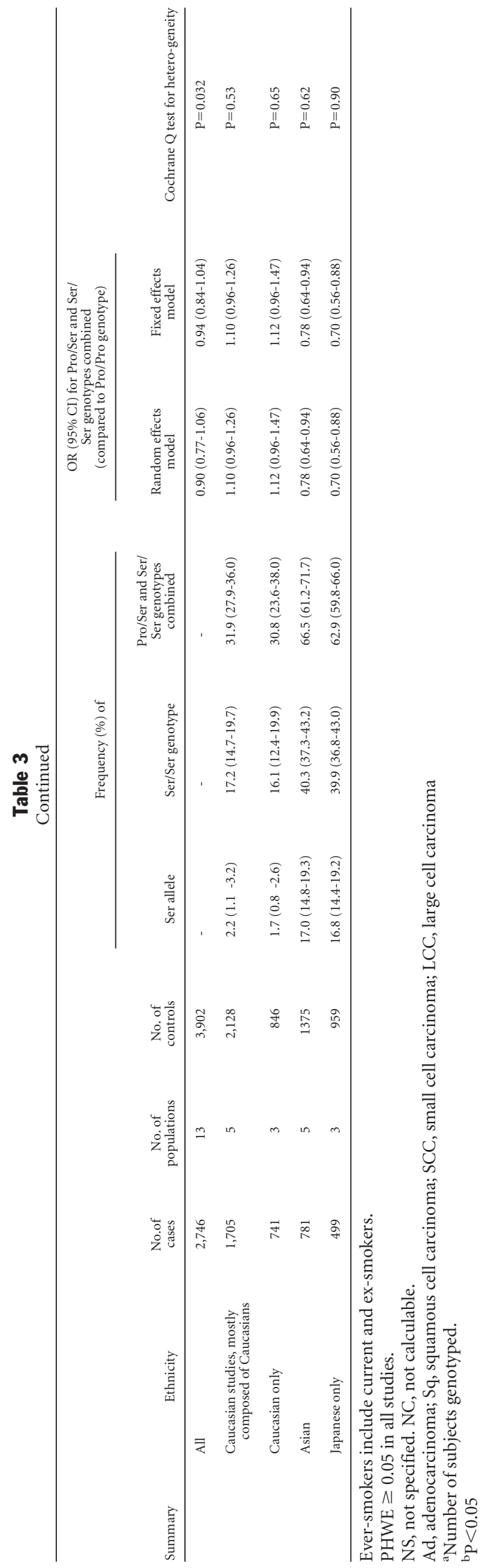

of the Pro allele $(\mathrm{OR}=0.26,95 \% \mathrm{CI}=0.08-0.84) .{ }^{26} \mathrm{In}$ Chinese, the combined genotype relative to the Pro/Pro genotype increased the OR for squamous cell carcinoma $(3.23,95 \%$ CI $=1.00-10.38){ }^{60}$ In Caucasians, the Pro/Ser and Ser/Ser genotypes combined was significantly associated with increased risk of squamous cell carcinoma $(\mathrm{OR}=2.21,95 \% \mathrm{CI}=$ 1.03-4.84). ${ }^{29}$ The Ser/Ser genotype was significantly associated with decreased risk for adenocarcinoma among Japanese (OR $=0.47,95 \% \mathrm{CI}=0.22-0.97) . .^{54}$ There was no association between NQO1 genotype and lung cancer risk, regardless of histologic type. ${ }^{46,63}$ In subgroup analyses by histologic type among Caucasians and Asians, the Pro/Ser and Ser/Ser genotypes combined was marginally associated with increased risk of squamous cell carcinoma $(\mathrm{OR}=1.29,95 \% \mathrm{CI}=0.97-1.72)$, whereas the combined genotype was not associated with increased risk of adenocarcinoma $(\mathrm{OR}=0.89,95 \% \mathrm{CI}=0.71-$ 1.13) (data not shown). The decreased risk $(\mathrm{OR}=0.79,95 \%$ $\mathrm{CI}=0.59-1.07)$ was observed for adenocarcinoma patients with the combined genotype among Asians, however (data not shown). There was no clear evidence of the different role of NQO1 among different histologic types, however.

\section{MPO G-463A polymorphism and lung cancer risk}

As the variant allele is related to low metabolic activation activity, subjects with at least one variant allele may be associated with decreased risk of lung cancer. London et al.79 first reported that subjects with the A/A genotype were significantly associated with decreased risk of lung cancer in Caucasians and a nonsignificant reduction in African Americans compared with those with the G/G genotype.A second study ${ }^{82}$ of populations with Caucasian, Japanese, or Hawaiian ethnicity reported a significant reduction in risk for those with the $\mathrm{A} / \mathrm{A}$ genotype compared with those with the G/G genotype in only a Japanese population. Also, the A/A genotype was associated with decreased risk of lung cancer among an American population..$^{91}$ In subsequent Caucasian (or mostly Caucasians) studies, $72,73,83,92$ the A/A genotype was suggested as being a protective factor for lung cancer. However, the G/A and A/A genotypes combined was associated with increased risk of lung cancer among a subset of Caucasian men of $>64$ years old $(\mathrm{OR}=2.92,95 \% \mathrm{CI}=1.33-6.43) .{ }^{72} \mathrm{~A}$ statistically significant reduced risk of lung cancer was observed for the G/A and A/A genotypes combined among Caucasian men $(\mathrm{OR}=0.55,95 \% \mathrm{CI}$ $=0.36-0.84)$, but not among women $(\mathrm{OR}=0.81,95 \% \mathrm{CI}=$ $0.55-1.26){ }^{92}$ The A/A genotype was nonsignificantly associated with increased risk of lung cancer among Caucasians. ${ }^{85}$ No evidence for an influence of genetic polymorphism in MPO on lung cancer risk was found in three Caucasian populations ${ }^{74,80,90}$ and one Chinese population. ${ }^{99}$

The 12 case-control studies of lung cancer among 15 ethnic groups and MPO genotype included 4285 lung cancer cases and 4656 controls. Although biological effects of each genotype have not been clarified, the previous meta-analysis suggested that the MPO activity was different among the three genotypes. ${ }^{83}$ We used the genetic model (lung cancer risks of the genotypes $\mathrm{G} / \mathrm{G}, \mathrm{G} / \mathrm{A}$, and $\mathrm{A} / \mathrm{A}$ decrease in that order), 


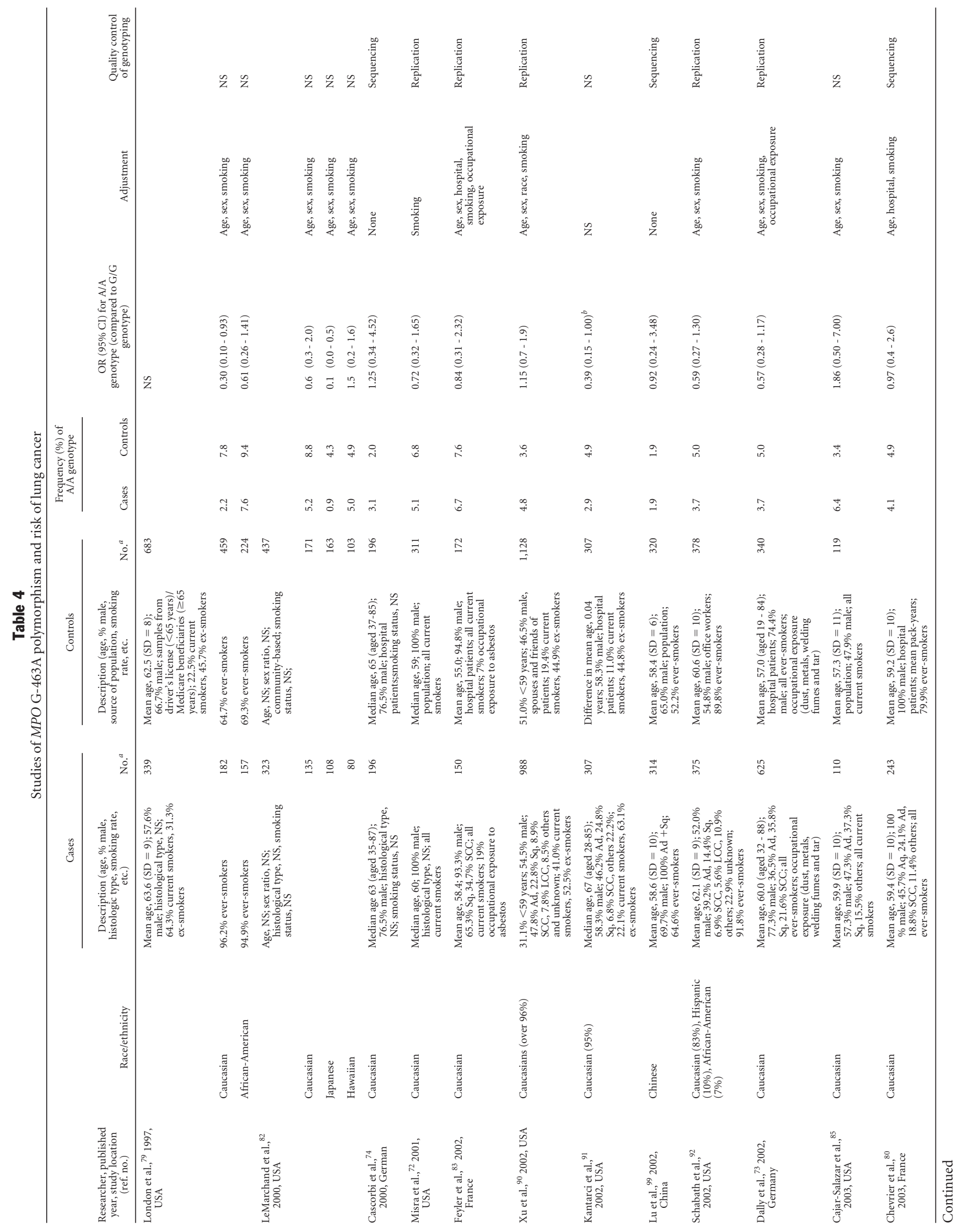




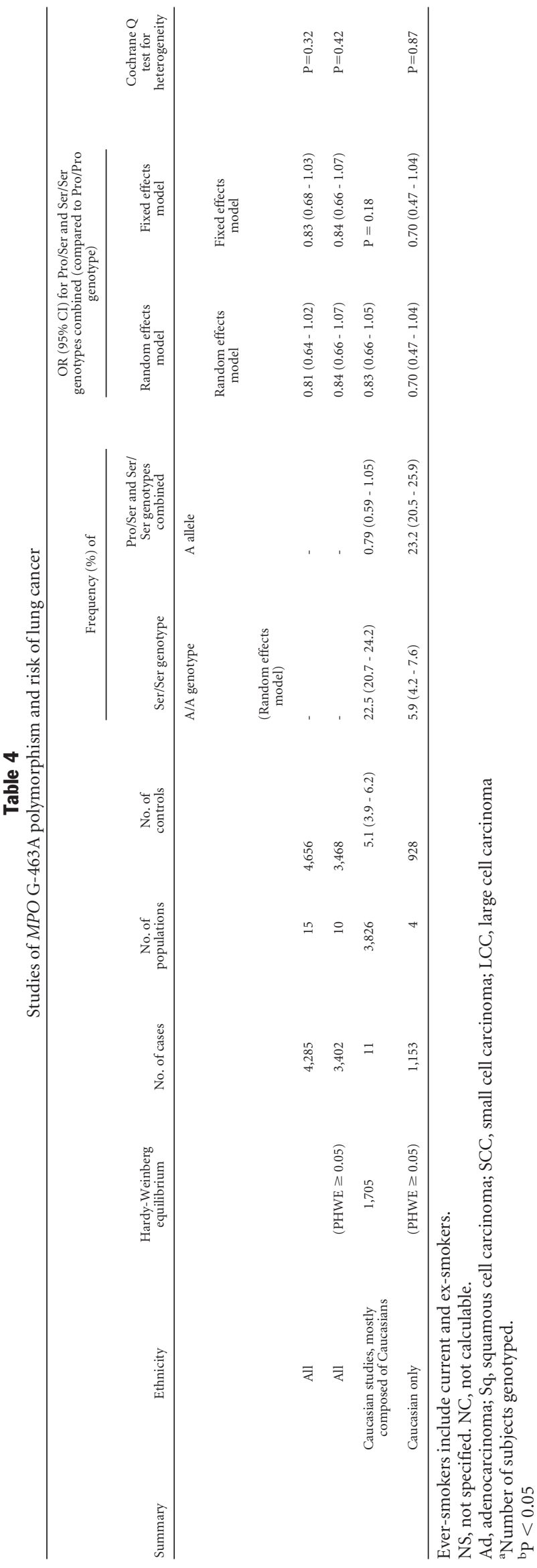

which was applied to our meta-analysis of the studies on NQO1 polymorphism and lung cancer. The summary OR for the A/A genotype was $0.81(95 \% \mathrm{CI}=0.64-1.02)$ (Table $4)$. The summary OR for the A/A genotype among Caucasian only studies with $\mathrm{P}_{\mathrm{HWE}} \geq 0.05$ was 0.70 (95\% CI $=0.47$ - 1.04). The Egger's test was statistically significant $(P=$ $0.007)$ for publication bias but not the Begg's test $(P=0.21)$ in a sensitivity analysis among all studies with $\mathrm{P}_{\mathrm{HWE}} \geq 0.05$, because the largest study of $\mathrm{Xu}$ et al. showed null association. ${ }^{91}$ Although the results concerning the association between lung cancer and the $M P O$ polymorphism are still a matter of debate, the OR of 0.7 suggests an important role for $M P O$ in lung cancer etiology among Caucasians, possibly through activation of carcinogens and/or production of free radicals in or near the target cells.

Of the 12 reports on the $M P O$ genotype and lung cancer risk, eight provide information on the $M P O$ genotype and lung cancer risk in histologic types. A significant protection of the A/A and G/A genotypes combined was seen among adenocarcinoma $(\mathrm{OR}=0.24,95 \% \mathrm{CI}=0.10-0.58)$ and squamous cell carcinoma $(\mathrm{OR}=0.39,95 \% \mathrm{CI}=0.18-0.82)$ cases. $^{74}$ In another study, a protective effect of the combined genotype was noted for adenocarcinoma $(\mathrm{OR}=0.64,95 \% \mathrm{CI}=0.42-0.96)$ cases and small cell carcinoma cases $(\mathrm{OR}=0.43,95 \% \mathrm{CI}=$ $0.17-1.05)$, but not for squamous cell carcinoma cases $(\mathrm{OR}=$ $0.99,95 \% \mathrm{CI}=0.54-1.82) .{ }^{92}$ The decreased risk was significant for squamous cell carcinoma patients with the combined genotype $(\mathrm{OR}=0.42,95 \% \mathrm{CI}=0.25-0.71)$ but not for those with adenocarcinoma $(\mathrm{OR}=0.75,95 \% \mathrm{CI}=0.47-1.20) .{ }^{99}$ The OR for the A/A genotype for squamous cell carcinoma was $0.49(95 \% \mathrm{CI}=0.27-0.88) .{ }^{83} \mathrm{~A}$ reduction in risk, although not statistically significant $(\mathrm{OR}=0.66,95 \% \mathrm{CI}=0.28-1.52)$, was also observed for small cell carcinoma patients with the A/A genotype. ${ }^{83}$ Furthermore, a protective effect of the A/A and G/A genotypes combined was seen among patients with small cell carcinoma $(\mathrm{OR}=0.58,95 \% \mathrm{CI}=0.36-0.95)$ but not patients with squamous cell carcinoma $(\mathrm{OR}=0.82,95 \% \mathrm{CI}=$ $0.56-1.21)$ and adenocarcinoma $(\mathrm{OR}=0.81,95 \% \mathrm{CI}=$ $0.55-1.19) .{ }^{73}$ In contrast, the A/A genotype was associated with increased risk of squamous cell carcinoma $(\mathrm{OR}=1.82,95 \% \mathrm{CI}$ $=0.8-4.1)$ and adenocarcinoma $(\mathrm{OR}=1.36,95 \% \mathrm{CI}=$ $0.8-2.5) .{ }^{89}$ No significant association for the $M P O$ genotype and patients with squamous cell carcinoma or adenocarcinoma was observed. ${ }^{82}$ There was also no clear evidence of lung cancer risk by histologic types. ${ }^{80}$ Stratification by histologic type yielded an OR of $0.91(95 \% \mathrm{CI}=0.45-1.84)$ for adenocarcinoma and $1.33(95 \% \mathrm{CI}=0.73-2.42)$ for squamous cell carcinoma (data not shown). These results may largely be affected by the study of Xu et al. ${ }^{90}$ (more than one third of cases and nearly two thirds of controls were included). Taken together, results on the $M P O$ genotype and risk for different histologic types of lung cancer are conflicting and suggest that confounders that have not been controlled for may have interfered with the analysis. 


\section{GENE-ENVIRONMENT INTERACTIONS}

\section{NQ01 Pro187Ser polymorphism}

The excess small cell lung cancer risk associated with the presence of the Ser allele was apparent in heavy smokers where the OR for the Ser/Ser and Pro/Ser genotypes combined was 12.5 (95\% CI $=2.10-75.5)$; in light smokers the OR was 0.90 $(95 \% \mathrm{CI}=0.08-9.60) .{ }^{26}$ In contrast, the frequency of NQO1 genotypes did not differ significantly between smokers and nonsmokers. ${ }^{60}$ Current smokers with the Ser/Ser genotype had a smaller lung cancer risk than current smokers with the Pro/ Pro and Pro/Ser genotypes combined; the OR for the Ser/Ser genotype versus the Pro/Pro genotype was 0.38 (95\% CI = 0.19-1.00). ${ }^{46}$ However, there was no statistically significant interaction between NQO1 genotypes and smoking. ${ }^{46}$ The ORs for the Ser/Ser genotype were $0.42(95 \% \mathrm{CI}=0.18-1.10)$ in smokers and $0.34(95 \% \mathrm{CI}=0.08-1.33)$ in nonsmokers. ${ }^{54}$ Therefore, the result showed that the association of the NQO1 polymorphism with lung adenocarcinoma risk appeared to be equal both in smokers and nonsmokers. ${ }^{54}$ The NQO1 genotype distribution in cases was similar to that found among controls in never, light and heavy smokers with ORs close to unity within each smoking group. ${ }^{29}$ Only one ${ }^{26}$ of five studies $^{26,29,46,54,60}$ suggested a possible interaction between NQO1 genotypes and smoking upon investigation. Significant interaction can be seen when accurate categorization of tobacco exposure is used instead of a ternary variable, such as never, ex- and current smokers.

\section{MPO G-463A polymorphism}

Four studies suggested the existence of an interaction between MPO genotype and cigarette smoking. ${ }^{72,73,92,99}$ The association between MPO genotype and lung cancer risk was modified by duration of smoking $(\mathrm{P}$ for interaction $=0.014) .{ }^{72}$ Among heavy smokers ( $\geq 26$ pack-years) with the G/A and A/A genotypes combined, the OR for squamous cell carcinoma was $6.22(95 \% \mathrm{CI}=1.72-22.47)$, against $1.39(95 \% \mathrm{CI}=0.29-$ 6.57) among light smokers with the combined genotype. ${ }^{99}$ No such gene-smoking interaction was observed for adenocarcinoma, however. ${ }^{99}$ There was a protective effect for the G/A and $\mathrm{A} / \mathrm{A}$ genotypes combined in ever smokers $(\mathrm{OR}=0.63,95 \% \mathrm{CI}$ $=0.45-0.87)$, but no effect in never smokers $(\mathrm{OR}=1.14,95 \%$ $\mathrm{CI}=0.42-3.11) .{ }^{92} \mathrm{~A}$ significant protective effect for individuals with the G/A and A/A genotypes combined with the lowest tertile of $<30$ pack-years $(\mathrm{OR}=0.39,95 \% \mathrm{CI}=0.19-0.82)$. The cross-product interaction term between MPO genotype and pack-years was significant ( $\mathrm{P}$ for interaction $=0.025) .{ }^{92} \mathrm{~A}$ protective effect for the A/A genotype was also found only in groups with lower tobacco consumption $(\mathrm{OR}=0.43,95 \% \mathrm{CI}$ $=0.25-0.74)$, and heavy smoking abolished the MPO-related effect $(\mathrm{OR}=1.03,95 \% \mathrm{CI}=0.69-1.55) .{ }^{73}$ Three studies $^{79,83,90}$ found no evidence of interaction between MPO genotypes and smoking. Two of these three studies measured tobacco smoking as a binary variable, such as nonsmokers and smokers. Assessment of gene-environment interaction should begin with appropriate measurement of tobacco smoking and large sample size.

\section{GENE-GENE INTERACTIONS}

\section{NQ01 Pro187Ser polymorphism}

Interactions between NQO1 and other genes have been investigated in three studies. ${ }^{29,53,54}$ The combined NQO1 Pro/ Pro and GSTT1 null genotypes showed a significant association with lung adenocarcinoma risk. When using the NQO1 Ser/Ser and GSTT1 non-null genotypes combined as a reference, the OR for the NQO1 Pro/Pro and GSTT1 null genotypes combined was 4.61 (95\% CI $=1.59-13.34) .{ }^{54}$ A gene-gene interaction was suggested between NQO1 and T3801C/ A2455G (Ile462Val) polymorphisms combined of CYP1A1. ${ }^{29}$ The OR for squamous cell carcinoma was higher in the group with the combined variant genotypes of NQO1 and CYP1A1 $(\mathrm{OR}=3.54,95 \% \mathrm{CI}=0.88-14.3)$ compared with the ORs in the groups with only one of the NQO1 variant genotype $(\mathrm{OR}=$ $1.69,95 \% \mathrm{CI}=0.85-3.39)$ and only one of the CYP1A1 variant genotype $(\mathrm{OR}=1.36,95 \% \mathrm{CI}=0.46-3.90)$. However, no evidence was seen for effects of gene-gene interactions (all possible combinations of two genotypes for NQO1, CYP1A1, GSTM1, and GSTT1) on lung cancer risk. ${ }^{53}$ In addition to adequate sample size, assessment of gene-gene interaction also depends upon the proper statistical evaluation of interaction on the multiplicative and additive models. Again, if such genegene interaction indeed exists, it may be hampered by the small sample size.

\section{MPO G-463A polymorphism}

Only two studies examined whether the association between $M P O$ genotype and lung cancer risk was modified by other genes. ${ }^{83,85}$ The $M P O$ G/A genotype interacted with the presence of GSTT1 $(\mathrm{OR}=0.12,95 \% \mathrm{CI}=0.02-0.71)$ and of both GSTM1 and GSTT1 genotypes $(\mathrm{OR}=0.02,95 \% \mathrm{CI}=0.01-$ $0.50)$ to significantly decrease lung cancer among males but not in females. ${ }^{85}$ On the other hand, no differences in risks associated with $M P O$ genotypes were found according to GSTM1, CYP1A1 T3801C, or CYP1A1 A2455G (Ile462Val) genotype. ${ }^{83}$ Nointeraction would either suggest that these proteins do not participate in the same pathway or, more likely, that there are backup or redundant mechanisms that compensate for the diminished or altered function of different enzymes.

Among smokers who smoked $\leq 25$ pack-years, a significant reduction in risk for lung cancer was observed among individuals who had the MPO G/A genotype combined and the presence of GSTT1, compared with who had the MPO G/G genotype and GSTT1 null genotype (OR $=0.03,95 \% \mathrm{CI}=$ 0.01-0.79). ${ }^{85}$ Gene-gene-environment interaction was suggested despite the limited power for assessing three-way interaction. This finding must be interpreted with caution and needs to be validated in larger studies. 


\section{Laboratory testing}

Methods of genotyping for $N Q O 1^{146}$ and $M P O{ }^{79}$ by means of the polymerase chain reaction and restriction fragment length polymorphism techniques have been described previously.

\section{POPULATION TESTING}

To date, there is insufficient evidence implicating NQO1 or $M P O$ in the etiology of lung cancer to make population testing an issue.

\section{OTHER POTENTIAL PUBLIC HEALTH APPLICATONS}

At this writing, the available data are insufficient to support any public health recommendations.

\section{DISCUSSION AND RECOMMENDATIONS FOR RESEARCH}

The variant allele of NQO1 Pro187Ser was associated with a $22 \%$ to $30 \%$ decrease in lung cancer risk among Asians. However, there are several conflicting reports on the association between this polymorphism and lung cancer risk among various populations. Although the reasons for the inconsistencies in the studies are not clear, possible explanations are as follows: (1) low frequency of the "at risk" genotype, which reduces the statistical power and (2) small size of the studies. Ethnic differences in roles of the polymorphism may be caused by genegene interactions, different linkages to the polymorphisms determining lung cancer risk and different lifestyles. On the other hand, the variant allele of MPO G-463A polymorphism was associated with decreased risk (30\%) of lung cancer among Caucasians because most studies have been done on them. Thus, both polymorphisms appear to be candidates for lung cancer susceptibility genes. Although the summary risk for developing lung cancer in individuals with at each "at risk" genotype may be small, lung cancer is such a common malignancy that even a small increase in risk translates to a large number of excess lung cancer cases in the population. Therefore, polymorphisms, even those not significantly associated with lung cancer, should be considered an important public health issue.

Research into the role of NQO1 and MPO polymorphisms in lung cancer is not in the last stages. The etiology of lung cancer cannot be explained by allelic variability at a single locus. Advances in identification of new variants and in highthroughput genotyping techniques will facilitate analysis of multiple polymorphisms within the genes with the same pathway. ${ }^{147}$ Therefore, it is likely that the defining feature of future epidemiologic studies will be the simultaneous analysis of large samples of cases and controls. ${ }^{148,149}$ The major burden of lung cancer in the population probably results from complex interaction between many genetic and environmental factors over time. The effects of polymorphisms are best represented by their haplotypes. Recently developed haplotypebased methods were not used in the studies we reviewed; however, it can be anticipated that in future association studies on lung cancer, the development of new approaches will facilitate the evaluation of haplotypic effects, either for selected polymorphisms physically close to each other or for multiple genes within the same drug-metabolism pathway.

\section{References}

1. Lind C, Cadenas E, Hochstein P, Ernster L. DT-diaphorase: purification, properties, and function. Methods Enzymol 1990;186:287-301.

2. Joseph P, Jaiswal AK. NAD(P)H:quinone oxidoreductasel (DT diaphorase) specifically prevents the formation of benzo[a]pyrene quinone-DNA adducts generated by cytochrome P4501Al and P450 reductase. Proc Natl Acad Sci U S A 1994; 91:8413-8417.

3. De Flora S, Bennicelli C, D'Agostini F, Izzotti A, Camoirano A. Cytosolic activation of aromatic and heterocyclic amines. Inhibition by dicoumarol and enhancement in viral hepatitis B. Environ Health Perspect 1994;102(Suppl 6):69-74.

4. Siegel D, Ross D. Immunodetection of $\operatorname{NAD}(\mathrm{P}) \mathrm{H}$ :quinone oxidoreductase 1 (NQO1) in human tissues1. Free Rad Biol Med 2000;29:246-253.

5. Weil SC, Rosner GL, Reid MS, Chisholm RL, Farber NM, Spitznagel JK, et al. cDNA cloning of human myeloperoxidase: decrease in myeloperoxidase mRNA upon induction of HL-60 cells. Proc Natl Acad Sci U S A 1987;84:2057-2061.

6. Klebanoff SJ. Myeloperoxidase: occurrence and biological function. In: Everse J, Everse KE, Grisham MB, editors. Peroxidases in Chemistry and Biology. Vol. 1, Boca Raton, FL.; CRC Press, Inc., 1991: 1-35.

7. Hunninghake GW, Gadek JE, Kawanami O, Ferrans VJ, Crystal RG. Inflammatory and immune processes in the human lung in health and disease: evaluation by bronchoalveolar lavage. Am J Pathol 1979;97:149-206.

8. Schmekel B, Hornblad Y, Linden M, Sundstrom C, Venge P. Myeloperoxidase in human lung lavage. II. Internalization of myeloperoxidase by alveolar macrophages. Inflammation 1990;14:455-461.

9. Schmekel B, Karlsson SE, Linden M, Sundstrom C, Tegner H, Venge P. Myeloperoxidase in human lung lavage. I. A marker of local neutrophil activity. Inflammation 1990;14:447-454.

10. Mallet WG, Mosebrook DR, Trush MA. Activation of (+/-)-trans-7,8-dihydroxy7,8-dihydrobenzo[a]pyrene to diolepoxides by human polymorphonuclear leukocytes or myeloperoxidase. Carcinogenesis 1991;12:521-524.

11. Petruska JM, Mosebrook DR, Jakab GJ, Trush MA. Myeloperoxidase-enhanced formation of (+/-)-trans-7,8-dihydroxy-7,8-dihydrobenzo[a]pyrene-DNA adducts in lung tissue in vitro: a role of pulmonary inflammation in the bioactivation of a procarcinogen. Carcinogenesis 1992;13:1075-1081.

12. Trush MA, Seed JL, Kensler TW. Oxidant-dependent metabolic activation of polycyclic aromatic hydrocarbons by phorbol ester-stimulated human polymorphonuclear leukocytes: possible link between inflammation and cancer. Proc Natl Acad Sci USA 1985;82:5194-5198.

13. Culp SJ, Roberts DW, Talaska G, Lang NP, Fu PP, Lay Jr. JO, et al. Immunochemical, 32P-postlabeling, and GC/MS detection of 4-aminobiphenyl-DNA adducts in human peripheral lung in relation to metabolic activation pathways involving pulmonary N-oxidation, conjugation, and peroxidation. Mutat Res 1997;378:97112.

14. Tsuruta Y, Josephy PD, Rahimtula AD, O’Brien PJ. Peroxidase-catalyzed benzidine binding to DNA and other macromolecules. Chem Biol Interact 1985;54:143-158.

15. Kadlubar FF, Butler MA, Kaderlik KR, Chou HC, Lang NP. Polymorphisms for aromatic amine metabolism in humans: relevance for human carcinogenesis. Environ Health Perspect 1992;98:69-74.

16. Williams JA, Stone EM, Millar BC, Gusterson BA, Grover PL, Phillips DH. Determination of the enzymes responsible for activation of the heterocyclic amine 2-amino-3-methylimidazo[4,5-f] quinoline in the human breast. Pharmacogenetics 1998;8:519-528.

17. Trush MA, Kensler TW. An overview of the relationship between oxidative stress and chemical carcinogenesis. Free Radic Biol Med 1991;10:201-9.

18. Nichols BA, Bainton DF, Farquhar MG. Differentiation of monocytes. Origin, nature, and fate of their azurophil granules. J Cell Biol 1971;50:498-515.

19. Odeberg H, Olofsson T, Olsson I. Myeloperoxidase-mediated extracellular iodination during phagocytosis in granulocytes. Scand J Haematol 1974;12:155-160.

20. Bradley PP, Christensen RD, Rothstein G. Cellular and extracellular myeloperoxidase in pyogenic inflammation. Blood 1982;60:618-622.

21. Jaiswal AK, McBride OW, Adesnik M, Nebert DW. Human dioxin-inducible cytosolic NAD $(\mathrm{P}) \mathrm{H}$ :menadione oxidoreductase. cDNA sequence and localization of gene to chromosome 16. J Biol Chem 1988;263:13572-13578.

22. Traver RD, Horikoshi T, Danenberg KD, Stadlbauer TH, Danenberg PV, Ross D, et al. $\mathrm{NAD}(\mathrm{P}) \mathrm{H}$ :quinone oxidoreductase gene expression in human colon carcinoma 
cells: characterization of a mutation which modulates DT-diaphorase activity and mitomycin sensitivity. Cancer Res 1992;52:797-802.

23. Ross D, Traver RD, Siegel D, Kuehl BL, Misra V, Rauth AM. A polymorphism in $\mathrm{NAD}(\mathrm{P}) \mathrm{H}$ :quinone oxidoreductase (NQO1): relationship of a homozygous mutation at position 609 of the NQO1 cDNA to NQO1 activity. Br J Cancer 1996;74: 995-996.

24. Siegel D, McGuinness SM, Winski SL, Ross D. Genotype-phenotype relationships in studies of a polymorphism in $\mathrm{NAD}(\mathrm{P}) \mathrm{H}$ :quinone oxidoreductase 1. Pharmacogenetics 1999;9:113-121.

25. Kuehl BL, Paterson JW, Peacock JW, Paterson MC, Rauth AM. Presence of a heterozygous substitution and its relationship to DT-diaphorase activity. Br JCancer 1995; 72:555-561.

26. Lewis SJ, Cherry NM, Niven RM, Barber PV, Povey AC. Polymorphisms in the $\mathrm{NAD}(\mathrm{P}) \mathrm{H}$ : quinone oxidoreductase gene and small cell lung cancer risk in a UK population. Lung Cancer 2001;34:177-183.

27. Menzel HJ, Sarmanova J, Soucek P, Berberich R, Grunewald K, Haun M, et al. Association of NQO1 polymorphism with spontaneous breast cancer in two independent populations. Br J Cancer 2004;90:1989-1994.

28. Zhang J, Schulz WA, Li Y, Wang R, Zotz R, Wen D, et al. Association of NAD (P)H: quinone oxidoreductase 1 (NQO1) C609T polymorphism with esophageal squamous cell carcinoma in a German Caucasian and a northern Chinese population. Carcinogenesis 2003;24:905-909.

29. Alexandrie AK, Nyberg F, Warholm M, Rannug A. Influence of CYP1A1, GSTM1, GSTT1, and NQO1 genotypes and cumulative smoking dose on lung cancer risk in a Swedish population. Cancer Epidemiol Biomarkers Prev 2004;13:908-914.

30. Verdina A, Galati R, Falasca G, Ghittori S, Imbriani M, Tomei F, et al. Metabolic polymorphisms and urinary biomarkers in subjects with low benzene exposure. $J$ Toxicol Environ Health A 2001;64:607-618.

31. Steiner M, Hillenbrand M, Borkowsi M, Seiter H, Schuff-Werner P. 609 C $->$ T polymorphism in $\mathrm{NAD}(\mathrm{P}) \mathrm{H}$ :quinone oxidoreductase gene in patients with prostatic adenocarcinoma or benign prostatic hyperplasia. Cancer Lett 1999;135:67-71.

32. Smith MT, Wang Y, Kane E, Rollinson S, Wiemels JL, Roman E, et al. Low NAD(P)H:quinone oxidoreductase 1 activity is associated with increased risk of acute leukemia in adults. Blood 2001;97:1422-1426.

33. Krajinovic M, Sinnett H, Richer C, Labuda D, Sinnett D. Role of NQO1, MPO and CYP2E1 genetic polymorphisms in the susceptibility to childhood acute lymphoblastic leukemia. Int J Cancer 2002;97:230-236.

34. Mitrou P, Watson M, Bingham S, Stebbings WS, Speakman CT, Loktionov A NQO1 and $\mathrm{mEH}$ exon 4 (mEH4) gene polymorphisms, smoking and colorectal cancer risk. IARC Sci Publ 2002;156:495-497.

35. Park SJ, Zhao H, Spitz MR, Grossman HB, Wu X. An association between NQO1 genetic polymorphism and risk of bladder cancer. Mutat Res 2003;536:131-137.

36. Kiffmeyer WR, Langer E, Davies SM, Envall J, Robison LL, Ross JA. Genetic polymorphisms in the Hmong population: implications for cancer etiology and survival. Cancer 2004;100:411-417.

37. Harth V, Donat S, Ko Y, Abel J, Vetter H, Bruning T. NAD $(\mathrm{P}) \mathrm{H}$ quinone oxidoreductase 1 codon 609 polymorphism and its association to colorectal cancer. Arch Toxicol 2000;73:528-531.

38. Sanyal S, Festa F, Sakano S, Zhang Z, Steineck G, Norming U, et al. Polymorphisms in DNA repair and metabolic genes in bladder cancer. Carcinogenesis 2004;25:729_ 734.

39. Longuemaux S, Delomenie C, Gallou C, Mejean A, Vincent-Viry M, Bouvier R, et al. Candidate genetic modifiers of individual susceptibility to renal cell carcinoma: a study of polymorphic human xenobiotic-metabolizing enzymes. Cancer Res 1999;59:2903-2908

40. Chen H, Lum A, Seifried A, Wilkens LR, Le Marchand L. Association of the NAD (P)H:quinone oxidoreductase $609 \mathrm{C}->\mathrm{T}$ polymorphism with a decreased lung cancer risk. Cancer Res 1999;59:3045-3058.

41. Seedhouse C, Bainton R, Lewis M, Harding A, Russell N, Das-Gupta E. The genotype distribution of the XRCC1 gene indicates a role for base excision repair in the development of therapy-related acute myeloblastic leukemia. Blood 2002;100:3761-3766.

42. Bartsch H, Malaveille C, Lowenfels AB, Maisonneuve P, Hautefeuille A, Boyle P. Genetic polymorphism of $\mathrm{N}$-acetyltransferases, glutathione S-transferase M1 and $\mathrm{NAD}(\mathrm{P}) \mathrm{H}$ :quinone oxidoreductase in relation to malignant and benign pancreatic disease risk. The International Pancreatic Disease Study Group. Eur J Cancer Prev 1998;7:215-223.

43. Rosvold EA, McGlynn KA, Lustbader ED, Buetow KH. Identification of an NAD(P)H:quinone oxidoreductase polymorphism and its association with lung cancer and smoking. Pharmacogenetics 1995;5:199-206.

44. Wiemels JL, Pagnamenta A, Taylor GM, Eden OB, Alexander FE, Greaves MF. A lack of a functional $\mathrm{NAD}(\mathrm{P}) \mathrm{H}$ :quinone oxidoreductase allele is selectively associated with pediatric leukemias that have MLL fusions. United Kingdom Childhood Cancer Study Investigators. Cancer Res 1999;59:4095-4099.
45. Olson SH, Carlson MD, Ostrer H, Harlap S, Stone A, Winters M, et al. Genetic variants in SOD2, MPO, and NQO1, and risk of ovarian cancer. Gynecol Oncol 2004;93:615-620

46. Xu LL, Wain JC, Miller DP, Thurston SW, Su L, Lynch TJ, et al. The NAD $(\mathrm{P}) \mathrm{H}$ : quinone oxidoreductase 1 gene polymorphism and lung cancer: differential susceptibility based on smoking behavior. Cancer Epidemiol Biomarkers Prev 2001;10: 303-309.

47. Morin S, Bodin L, Loriot MA, Thijssen HH, Robert A, Strabach S, et al. Pharmacogenetics of acenocoumarol pharmacodynamics. Clin Pharmacol Ther 2004;75 403-414.

48. Schulz WA, Krummeck A, Rosinger I, Eickelmann P, Neuhaus C, Ebert T, et al Increased frequency of a null-allele for $\mathrm{NAD}(\mathrm{P}) \mathrm{H}$ : quinone oxidoreductase in patients with urological malignancies. Pharmacogenetics 1997;7:235-239.

49. Fern L, Pallis M, Ian Carter G, Seedhouse C, Russell N, Byrne J. Clonal haemopoiesis may occur after conventional chemotherapy and is associated with accelerated telomere shortening and defects in the NQO1 pathway; possible mechanisms leading to an increased risk of t-AML/MDS. Br J Haematol 2004;126:63-71.

50. Hung RJ, Boffetta P, Brennan P, Malaveille C, Gelatti U, Placidi D, et al. Genetic polymorphisms of MPO, COMT, MnSOD, NQO1, interactions with environmental exposures and bladder cancer risk. Carcinogenesis 2004;25:973-978.

51. Choi JY, Lee KM, Cho SH, Kim SW, Choi HY, Lee SY, et al. CYP2E1 and NQO1 genotypes, smoking and bladder cancer. Pharmacogenetics 2003;13:349-355.

52. Hori $\mathrm{H}$, Ohmori O, Matsumoto C, Shinkai T, Nakamura J. NAD(P)H:quinone oxidoreductase (NQO1) gene polymorphism and schizophrenia. Psychiatry Res 2003;118:235-239.

53. Hamajima N, Matsuo K, Iwata H, Shinoda M, Yamamura $\mathrm{Y}$, Kato $\mathrm{T}$, et al $\mathrm{NAD}(\mathrm{P}) \mathrm{H}$ : quinone oxidoreductase 1 (NQO1) C609T polymorphism and the risk of eight cancers for Japanese. Int J Clin Oncol 2002;7:103-108.

54. Sunaga N, Kohno T, Yanagitani N, Sugimura H, Kunitoh H, Tamura T, et al Contribution of the NQO1 and GSTT1 polymorphisms to lung adenocarcinoma susceptibility. Cancer Epidemiol Biomarkers Prev 2002;11:730-738.

55. Fowke JH, Shu XO, Dai Q, Shintani A, Conaway CC, Chung FL, et al. Urinary isothiocyanate excretion, brassica consumption, and gene polymorphisms among women living in Shanghai, China. Cancer Epidemiol Biomarkers Prev 2003;12:1536-1539.

56. Winski SL, Swann E, Hargreaves RH, Dehn DL, Butler J, Moody CJ, et al. Relationship between $\mathrm{NAD}(\mathrm{P}) \mathrm{H}$ :quinone oxidoreductase 1 (NQO1) levels in a series of stably transfected cell lines and susceptibility to antitumor quinones. Biochem Pharmacol 2001;61:1509-1516.

57. Harada S, Fujii C, Hayashi A, Ohkoshi N. An association between idiopathic Parkinson's disease and polymorphisms of phase II detoxification enzymes: glutathione S-transferase M1 and quinone oxidoreductase 1 and 2. Biochem Biophys Res Commun 2001;288:887-892.

58. Kawase H, Hamajima N, Tamakoshi A, Wakai K, Saito T, Tajima K. Triplex polymerase chain reactions with confronting two-pair primers (PCR-CTPP) for NQO1 C609T, GSTM1 and GSTT1 polymorphisms: a convenient genotyping method. Asian Pac J Cancer Prev 2003;4:67-70.

59. Zhang JH, Li Y, Wang R, Geddert H, Guo W, Wen DG, et al. NQO1 C609T polymorphism associated with esophageal cancer and gastric cardiac carcinoma in North China. World J Gastroenterol 2003;9:1390-1393.

60. Yin L, Pu Y, Liu TY, Tung YH, Chen KW, Lin P. Genetic polymorphisms of $\mathrm{NAD}(\mathrm{P}) \mathrm{H}$ quinone oxidoreductase, CYP1Al and microsomal epoxide hydrolase and lung cancer risk in Nanjing, China. Lung Cancer 2001;33:133-41.

61. Zheng YX, Chan P, Pan ZF, Shi NN, Wang ZX, Pan J, et al. Polymorphism of metabolic genes and susceptibility to occupational chronic manganism. Biomarkers 2002;7:337-346.

62. Wan J, Shi J, Hui L, Wu D, Jin X, Zhao N, et al. Association of genetic polymorphisms in CYP2E1, MPO, NQO1, GSTM1, and GSTT1 genes with benzene poisoning. Environ Health Perspect 2002;110:1213-1218.

63. Lin P, Hsueh YM, Ko JL, Liang YF, Tsai KJ, Chen CY. Analysis of NQO1, GSTP1, and MnSOD genetic polymorphisms on lung cancer risk in Taiwan. Lung Cancer 2003;40:123-129.

64. Wiencke JK, Spitz MR, McMillan A, Kelsey KT. Lung cancer in Mexican-Americans and African-Americans is associated with the wild-type genotype of the NAD(P)H:quinone oxidoreductase polymorphism. Cancer Epidemiol Biomarkers Prev 1997;6:87-92.

65. Moore LE, Wiencke JK, Bates MN, Zheng S, Rey OA, Smith AH. Investigation of genetic polymorphisms and smoking in a bladder cancer case-control study in Argentina. Cancer Lett 2004;211:199-207.

66. Nebert DW, Roe AL, Vandale SE, Bingham E, Oakley GG. NAD(P)H:quinone oxidoreductase (NQO1) polymorphism, exposure to benzene, and predisposition to disease: a HuGE review. Genet Med 2002;4:62-70. 
67. Piedrafita FJ, Molander RB, Vansant G, Orlova EA, Pfahl M, Reynolds WF. An Alu element in the myeloperoxidase promoter contains a composite SP1-thyroid hormone-retinoic acid response element. J Biol Chem 1996;271:14412-14420.

68. Austin GE, Lam L, Zaki SR, Chan WC, Hodge T, Hou J, et al. Sequence comparison of putative regulatory DNA of the $5^{\prime}$ flanking region of the myeloperoxidase gene in normal and leukemic bone marrow cells. Leukemia 1993;7:1445-1450.

69. Reynolds WF, Chang E, Douer D, Ball ED, Kanda V. An allelic association implicates myeloperoxidase in the etiology of acute promyelocytic leukemia. Blood 1997; 90:2730-2737.

70. Reynolds WF, Hiltunen M, Pirskanen M, Mannermaa A, Helisalmi S, Lehtovirta $\mathrm{M}$, et al. MPO and APOEepsilon4 polymorphisms interact to increase risk for AD in Finnish males. Neurology 2000;55:1284-1290.

71. Kantarci OH, Atkinson EJ, Hebrink DD, McMurray CT, Weinshenker BG. Association of a myeloperoxidase promoter polymorphism with multiple sclerosis. $J$ Neuroimmunol 2000;105:189-194.

72. Misra RR, Tangrea JA, Virtamo J, Ratnasinghe D, Andersen MR, Barrett M, et al Variation in the promoter region of the myeloperoxidase gene is not directly related to lung cancer risk among male smokers in Finland. Cancer Lett 2001;164: 161-167.

73. Dally H, Gassner K, Jager B, Schmezer P, Spiegelhalder B, Edler L, et al. Myeloperoxidase (MPO) genotype and lung cancer histologic types: the MPO -463 A allele is associated with reduced risk for small cell lung cancer in smokers. Int J Cancer 2002;102:530-535.

74. Cascorbi I, Henning S, Brockmoller J, Gephart J, Meisel C, Muller JM, et al. Substantially reduced risk of cancer of the aerodigestive tract in subjects with variant463A of the myeloperoxidase gene. Cancer Res 2000;60:644-649.

75. Nelissen I, Fiten P, Vandenbroeck K, Hillert J, Olsson T, Marrosu MG, et al. PECAM1, MPO and PRKAR1A at chromosome 17q21-q24 and susceptibility for multiple sclerosis in Sweden and Sardinia. J Neuroimmunol 2000;108:153-159.

76. Hoy A, Leininger-Muller B, Poirier O, Siest G, Gautier M, Elbaz A, et al. Myeloperoxidase polymorphisms in brain infarction. Association with infarct size and functional outcome. Atherosclerosis 2003;167:223-230.

77. Rutgers A, Heeringa P, Giesen JE, Theunissen RT, Jacobs H, Tervaert JW. Neutrophil myeloperoxidase activity and the influence of two single-nucleotide promoter polymorphisms. Br J Haematol 2003;123:536-538.

78. Rothkrantz-Kos S, Drent M, Rutgers A, Heeringa P, De Vries J, van Dieijen-Visser MP, et al. Relationship between myeloperoxidase promotor polymorphism and disease severity in sarcoidosis. Eur J Intern Med 2003;14:296-301.

79. London SJ, Lehman TA, Taylor JA. Myeloperoxidase genetic polymorphism and lung cancer risk. Cancer Res 1997;57:5001-5003.

80. Chevrier I, Stucker I, Houllier AM, Cenee S, Beaune P, Laurent-Puig P, et al. Myeloperoxidase: new polymorphisms and relation with lung cancer risk. Pharmacogenetics 2003;13:729-739.

81. Pakakasama S, Chen TT, Frawley W, Muller C, Douglass EC, Tomlinson GE. Myeloperoxidase promotor polymorphism and risk of hepatoblastoma. Int J Cancer 2003;106:205-207.

82. Le Marchand L, Seifried A, Lum A, Wilkens LR. Association of the myeloperoxidase -463G->a polymorphism with lung cancer risk. Cancer Epidemiol Biomarker Prev 2000;9:181-184.

83. Feyler A, Voho A, Bouchardy C, Kuokkanen K, Dayer P, Hirvonen A, et al. Meloperoxidase $-463 \mathrm{G}->$ a polymorphism and lung cancer risk. Cancer Epidemiol Biomarkers Prev 2002;11:1550-1554.

84. Nikpoor B, Turecki G, Fournier C, Theroux P, Rouleau GA. A functional myeloperoxidase polymorphic variant is associated with coronary artery disease in French-Canadians. Am Heart J 2001;142:336-339.

85. Cajas-Salazar N, Sierra-Torres CH, Salama SA, Zwischenberger JB, Au WW. Combined effect of MPO, GSTM1 and GSTT1 polymorphisms on chromosome aberrations and lung cancer risk. Int J Hyg Environ Health 2003;206:473-483.

86. Borgmann S, Endisch G, Hacker UT, Song BS, Fricke H. Proinflammatory genotype of interleukin-1 and interleukin-1 receptor antagonist is associated with ESRD in proteinase 3-ANCA vasculitis patients. Am J Kidney Dis 2003;41:933-942.

87. Crawford FC, Freeman MJ, Schinka JA, Morris MD, Abdullah LI, Richards D, et al. Association between Alzheimer's disease and a functional polymorphism in the myeloperoxidase gene. Exp Neurol 2001;167:456-459.

88. Van Schooten FJ, Boots AW, Knaapen AM, Godschalk RW, Maas LM, Borm PJ, et al. Myeloperoxidase (MPO) -463G->A reduces MPO activity and DNA adduct levels in bronchoalveolar lavages of smokers. Cancer Epidemiol Biomarkers Prev 2004;13:828-833.

89. Zappia M, Manna I, Serra P, Cittadella R, Andreoli V, La Russa A, et al. Increased risk for Alzheimer disease with the interaction of MPO and A2M polymorphisms. Arch Neurol 2004;61:341-344.

90. Xu LL, Liu G, Miller DP, Zhou W, Lynch TJ, Wain JC, et al. Counterpoint: the myeloperoxidase -463G->a polymorphism does not decrease lung cancer susceptibility in Caucasians. Cancer Epidemiol Biomarkers Prev 2002;11:1555-1559.
91. Kantarci OH, Lesnick TG, Yang P, Meyer RL, Hebrink DD, McMurray CT, et al. Myeloperoxidase $-463(\mathrm{G}->\mathrm{A})$ polymorphism associated with lower risk of lung cancer. Mayo Clin Proc 2002;77:17-22.

92. Schabath MB, Spitz MR, Hong WK, Delclos GL, Reynolds WF, Gunn GB, et al. A myeloperoxidase polymorphism associated with reduced risk of lung cancer. Lung Cancer 2002;37:35-40.

93. Meisel P, Krause T, Cascorbi I, Schroeder W, Herrmann F, John U, et al. Gender and smoking-related risk reduction of periodontal disease with variant myeloperoxidase alleles. Genes Immun 2002;3:102-106.

94. Leininger-Muller B, Hoy A, Herbeth B, Pfister M, Serot JM, Stavljenic-Rukavina M, et al. Myeloperoxidase G-463A polymorphism and Alzheimer's disease in the ApoEurope study. Neurosci Lett 2003;349:95-98.

95. Buraczynska K, Koziol-Montewka M, Majdan M, Ksiazek A. Polymorphisms of tumor necrosis factor and myeloperoxidase genes in patients with chronic renal failure on peritoneal dialysis. Mol Diagn 2003;7:175-180.

96. Zakrzewska-Pniewska B, Styczynska M, Podlecka A, Samocka R, Peplonska B, Barcikowska M, et al. Association of apolipoprotein E and myeloperoxidase genotypes to clinical course of familial and sporadic multiple sclerosis. Mult Scler 2004; 10:266-271.

97. Katsuda N, Hamajima N, Tamakoshi A, Wakai K, Matsuo K, Saito T, et al. Helicobacter pylori seropositivity and the myeloperoxidase G-463A polymorphism in combination with interleukin-1B C-31T in Japanese health checkup examinees. Jpn J Clin Oncol 2003;33:192-197.

98. Hamajima N, Matsuo K, Suzuki T, Nakamura T, Matsuura A, Tajima K, et al. Low expression myeloperoxidase genotype negatively associated with Helicobacter pylori infection. Jpn J Cancer Res 2001;92:488-493.

99. Lu W, Xing D, Qi J, Tan W, Miao X, Lin D. Genetic polymorphism in myeloperoxidase but not GSTM1 is associated with risk of lung squamous cell carcinoma in a Chinese population. Int J Cancer 2002;102:275-279.

100. Choi EH, Zimmerman PA, Foster CB, Zhu S, Kumaraswami V, Nutman TB, et al. Genetic polymorphisms in molecules of innate immunity and susceptibility to infection with Wuchereria bancrofti in South India. Genes Immun 2001;2:248-253.

101. Ahsan H, Chen Y, Kibriya MG, Islam MN, Slavkovich VN, Graziano JH, et al Susceptibility to arsenic-induced hyperkeratosis and oxidative stress genes myeloperoxidase and catalase. Cancer Lett 2003;201:57-65.

102. DeLeo FR, Goedken M, McCormick SJ, Nauseef WM. A novel form of hereditary myeloperoxidase deficiency linked to endoplasmic reticulum/proteasome degradation. J Clin Invest 1998;101:2900-2909.

103. Romano M, Dri P, Dadalt L, Patriarca P, Baralle FE. Biochemical and molecular characterization of hereditary myeloperoxidase deficiency. Blood 1997;90:41264134

104. Nauseef WM, Cogley M, Bock S, Petrides PE. Pattern of inheritance in hereditary myeloperoxidase deficiency associated with the R569W missense mutation. J Leukoc Biol 1998;63:264-269.

105. Hoy A, Tregouet D, Leininger-Muller B, Poirier O, Maurice M, Sass C, et al. Serum myeloperoxidase concentration in a healthy population: biological variations, familial resemblance and new genetic polymorphisms. Eur J Hum Genet 2001;9:780786.

106. Parkin DM, Bray F, Ferlay J, Pisani P. Estimating the world cancer burden: Globocan 2000. Int J Cancer 2001;94:153-156.

107. Whelan DM Ferlay SL Teppo L, Thomas DB. Cancer incidence in five continents, Vol. 8. Lyon, France: International Agency for Research on Cancer, 2002 (IARC Scientific Publication no. 155).

108. Ernster L. Impact of tobacco on women's health. In: Samet JM, Yoon S-Y, editors. Women and the tobacco epidemic: challenges for the 21st century. Geneva, Switzerland: World Health Organization, 2001: 1-16.

109. Wingo PA, Ries LA, Giovino GA, Miller DS, Rosenberg HM, Shopland DR, et al. Annual report to the nation on the status of cancer, 1973-1996, with a special section on lung cancer and tobacco smoking. J Natl Cancer Inst 1999;91:675-690.

110. Levi F, Franceschi S, La Vecchia C, Randimbison L, Te VC. Lung carcinoma trends by histologic type in Vaud and Neuchatel, Switzerland, 1974-1994. Cancer 1997; 79:906-914

111. Wynder EL, Muscat JE. The changing epidemiology of smoking and lung cancer histology. Environ Health Perspect 1995;103:143-148.

112. Patel AR, Obrams GI. Adenocarcinoma of the lung. Cancer Epidemiol Biomarker Prev 1995;4:175-180.

113. Travis WD, Lubin J, Ries L, Devesa S. United States lung carcinoma incidence trends: declining for most histologic types among males, increasing among females. Cancer 1996;77:2464-2470.

114. Charloux A, Quoix E, Wolkove N, Small D, Pauli G, Kreisman H. The increasing incidence of lung adenocarcinoma: reality or artefact? A review of the epidemiology of lung adenocarcinoma. Int J Epidemiol 1997;26:14-23. 


\section{Kiyohara et al.}

115. Sobue T, Ajiki W, Tsukuma H, Oshima A, Hanai A, Fujimoto I. Trends of lung cancer incidence by histologic type: a population-based study in Osaka, Japan. Jpn J Cancer Res 1999;90:6-15.

116. U.S. Surgeon General. 1981. Health Consequence of smoking — The Changing Cigarette. DHHS (PHS) 81-50156. Rockville, Md.

117. Hecht SS, Morse MA, Amin S, Stoner GD, Jordan KG, Choi CI, et al. Rapid singledose model for lung tumor induction in A/J mice by 4-(methylnitrosamino)-1-(3pyridyl)-1-butanone and the effect of diet. Carcinogenesis 1989;10:1901-1904.

118. Hoffmann D, Rivenson A, Murphy SE, Chung FL, Amin S, Hecht SS. Cigarette smoking and adenocarcinoma of the lung: the relevance of nicotine-derived $\mathrm{N}$ nitrosamines. J Smoking-Rel Disord 1993;4:165-190.

119. Hoffmann D, Brunnemann KD, Prokopczyk B, Djordjevic MV. Tobacco-specific $\mathrm{N}$-nitrosamines and Areca-derived N-nitrosamines: chemistry, biochemistry, carcinogenicity, and relevance to humans. J Toxicol Environ Health 1994;41:1-52.

120. Ezzati M, Lopez AD. Estimates of global mortality attributable to smoking in 2000. Lancet 2003;362:847-852.

121. Lung Cancer. In: Stewart BW, Kleihues P, editors. World Cancer Report. Lyon, France: IARC Press 2003; 182-187.

122. Wakai K, Seki N, Tamakoshi A, Kondo T, Nishino Y, Ito Y, et al. Japan Collaborative Cohort Study. Decrease in risk of lung cancer death in males after smoking cessation by age at quitting: findings from the JACC study. Jpn J Cancer Res 2001;92:821-828.

123. Zhong L, Goldberg MS, Parent ME, Hanley JA. Exposure to environmental tobacco smoke and the risk of lung cancer: a meta-analysis. Lung Cancer 2000;27:3-18.

124. Tredaniel J, Boffetta P, Saracci R, Hirsch A. Non-smoker lung cancer deaths attributable to exposure to spouse's environmental tobacco smoke. Int J Epidemiol 1997; 26:939-944.

125. Doll R, Peto R. The causes of cancer: quantitative estimates of avoidable risks of cancer in the United States today. J Natl Cancer Inst 1981;66:1191-1308.

126. Willett WC. Diet, nutrition, and avoidable cancer. Environ Health Perspect 1995; 103(Suppl 8):165-170.

127. Samet JM Cohen AJ. Air pollution and lung cancer. In: Holgate, ST, Samet JM, Koren HS, Maynard R, eds. Air pollution and health. San Diego. CA: Academic Press, 1999; 841-864.

128. Boffetta P, Nyberg F. Contribution of environmental factors to cancer risk. $\mathrm{Br} \mathrm{Med}$ Bull 2003;68:71-94.

129. National Research Council (NBC). Committee on Health Risks of Exposures to Radon, Board on Radiation Effects Research. Health effects of exposure to radon (BEIR VI). Washington, DC; National Academy Press, 1988.

130. Kamataki T. Metabolism of xenobiotics. In: Omura T, Ishimura Y, Fujii-Kuriyama Y, editors. Cytochrome P-450. 2nd Edition. Tokyo, Japan: Kodansha Ltd., 1993: 141-158.

131. Kiyohara C, Shirakawa T, Hopkin JM. Genetic polymorphism of enzymes involved in xenobiotic metabolism and the risk of lung cancer. Environ Health Prevent Med 2002;7:47-59.
132. Vineis P, Veglia F, Benhamou S, Butkiewicz D, Cascorbi I, Clapper ML, et al. CYP1A1 T3801 C polymorphism and lung cancer: a pooled analysis of 2451 cases and 3358 controls. Int J Cancer 2003;104:650-657.

133. Mannervik B, Awasthi YC, Board PG, Hayes JD, Di Ilio C, Ketterer B, et al. Nomenclature for human glutathione transferases. Biochem J 1992;282:305-306.

134. Meyer DJ, Gilmore KS, Coles B, Dalton K, Hulbert PB, Ketterer B. Structural distinction of rat GSH transferase subunit 10. Biochem J 1991;274:619.-

135. Kiyohara C, Yoshimasu K, Shirakawa T, Hopkin JM. Genetic polymorphisms and environmental risk of lung cancer: a review. Rev Environ Health 2004;19:15-38.

136. Hirvonen A. Polymorphic NATs and cancer predisposition. In: Vineis P, Malats N Lang M, D'Errico A, Caporaso N, Cuzick J, Boffetta P. editors. Metabolic Polymor phisms and Susceptibility to Cancer. Lyon, France: International Agency for Research on Cancer, (IARC Scientific Publications no. 148), 1999; 251-270.

137. Kiyohara C. Polymorphisms in DNA repair gene and associations with lung cancer risk. The Lung Perspective 2005;13:1-5 (in Japanese).

138. DerSimonian R, Laird N. Meta-analysis in clinical trials. Control Clin Trials 1986; 7:177-188

139. Cochran WG. The combination of estimates from different experiments. Biometrics 1954;10:101-129.

140. Whitehead A, Whitehead J. A general parametric approach to the meta-analysis of randomized clinical trials. Stat Med 1991;10:1665-1677.

141. Begg CB, Mazumdar M. Operating characteristics of a rank correlation test for publication bias. Biometrics 1994;50:1088-1101.

142. Egger M, Davey Smith G, Schneider M, Minder C. Bias in meta-analysis detected by a simple, graphical test. BMJ 1997;315:629-634.

143. Thompson SG. Why sources of heterogeneity in meta-analysis should be investigated. BMJ 1994;309:1351-1355

144. Faddy SC. Significant statistical heterogeneity in a meta-analysis of the usefulness of acetylcysteine for prevention of contrast nephropathy. Am J Cardiol 2004;94: 414.

145. Sutton AJ, Duval SJ, Tweedie RL, Abrams KR, Jones DR. Empirical assessment of effect of publication bias on meta-analyses. BMJ 2000;320:1574-1577.

146. Traver RD, Siegel D, Beall HD, Phillips RM, Gibson NW, Franklin WA, et al Characterization of a polymorphism in $\mathrm{NAD}(\mathrm{P}) \mathrm{H}$ :quinone oxidoreductase (DTdiaphorase). Br J Cancer 1997;75:69-75.

147. Goode EL, Ulrich CM, Potter JD. Polymorphisms in DNA repair genes and associations with cancer risk. Cancer Epidemiol Biomarkers Prev 2002;11:1513_ 1530.

148. Caporaso NE. Why have we failed to find the low penetrance genetic constituents of common cancers? Cancer Epidemiol Biomarkers Prev 2002;11:1544-1549.

149. Brennan P. Gene-environment interaction and aetiology of cancer: what does it mean and how can we measure it? Carcinogenesis 2002;23:381-387. 